
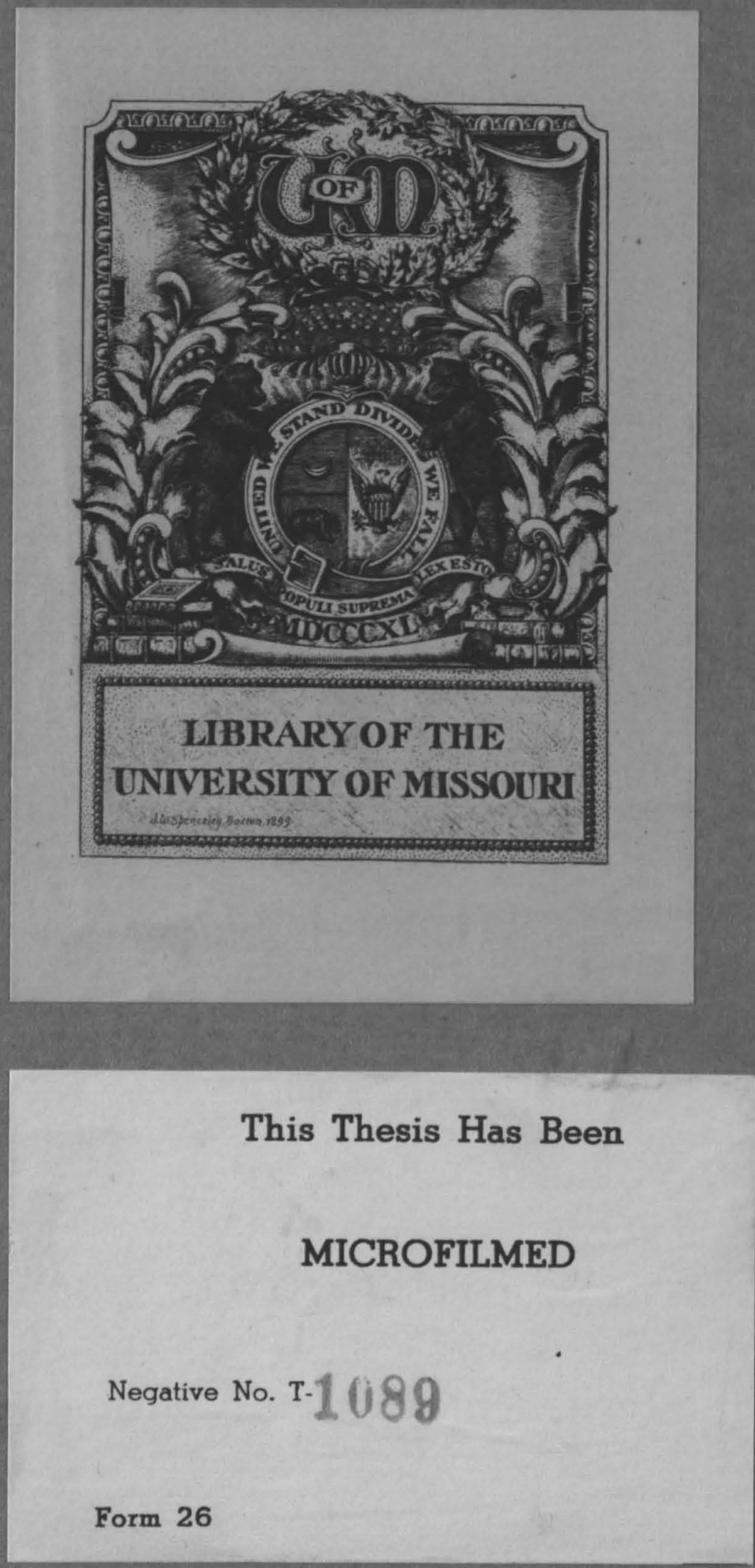
THE USE OF FATS IN COOKING.

by

Bessie May Naylor, B.S. in Ed.

\author{
SUBMITTED IN PARTIAL FULFILIENT OF THE \\ REQUIREMENTS FOR THE DEGREE OF \\ MASTER OF ARTS \\ in the \\ GRADUATE SCHOOL \\ of the \\ UNIVERSITY OF MISSOURI
}

I9I7 
$X N 232$

\section{THE USE OF FATS IN}

The cost of food is the all important question at the present time. Our people must be fed. The problem is to discover what available foods will give the most nutritive value at a minimum cost. When we observe that a pound of fat will give energy to the amount of 4080 calories, while a pound of bread give about 1200 calories, and a pound of beefsteak less than 1200 calories, we see the importance of fat as a fuel food." At the same time we must remember that fat furnishes only energy and can not be depended upon to take the place of the necessary proteins and mineral substance. The deficiency in the supply, and the consequent increase in price of the commonly used animal fats causes us to look for other fats which are available for use, and makes important the questions of their keeping qualities, their suitability for use in cooking, their digestibility, and their cost.

\section{AVAILABLE FATS}

The fats on the market now for food purposes include cottonseed oill and its products, corn oil, sesame oil, olive oil, peanut oil, butter fat, lard, beef fat and mutton fat.

Cottonseed 0il.

Cottonseed oil is an oil obtained by pressing the hulled seeds of the cotton plant. A ton of seeds contains 1.

Holde-Mueller, "Exam of Hydrocarbon Oils," pages 287-360 
about 50 gallons of oil. The impure brownigh red oil which results from the first pressing is allowed to stand so the impurities will settle and then the clear layer is drawn off. After being treated with from 10 to $15 \%$ of calstic soda the fat obtained is light yellow in color, odorless, and of mild flavor. The yellow color may be removed by the use of fullers earth or charcoal. The oil which congeals at about 10 degrees C, is chilled to crystallize out the stearin, and then pressed to extract the remaining oil which, having a congealing point of 0 degrees $C$, is called a winter oil. The stearin separated is used in the preparation of butter and lard substitutes.

The history of the cottonseed oil industry goes back to 1783 when a prize was offered for any planter who would express oil from a ton of seed. No one claimed the prize,but in 1826 a mill was used in South Carolina to exprese cotton seed oil. The industry gradually grew until by 1880 it had begun to reach important proportions. The value of the products from the 45 eatablishments at that time amounted to $\$ 7,690,000$.

As a food the oil was first used as an adulterant to soften lard intended for use in cold climateia. Later on the fluid oil was mixed with beef fat to form a compound and was put on the market under the name of compound or refined 1ard. After the public received it without objection all 2 "Cottonseed and Its Products," Farmers Bulletin No. 36. 
disguise was dropped and the products sold on their own merits under various trade names such as cottonseed salad oil, wesson oil, cottolene, snowdrift, white cliff shortening, etc., explanations such as the following being made in their advertisements. In a catalogue advertising Wesson oil is this statement:

"Wesson Oil (Cotton seed Oil) for salads, frying, and shortening-a pure, highly refined table oil."

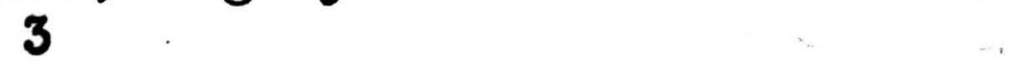

"Snowdrift, the pure food shortening, is made from best grade of refined cotton seed oil."

"Wite Cliff shortening is a pure, creamy white vegetable cooking fat, made from cotton seed oil by a special process."

$$
5 \text { is a lard substitute made from cottonseed }
$$
oil and beef suet.

The process of hydrogenation, by means of which the oils from the unsaturated fatty acids are made into solid fats is effected by adding hydrogen to the fat molecule making it have the composition and characteristics of the correaponding fats of the saturated series wich are at ordinary temperature solid fats. The hydrogen is passed through the heated fat in the presence of a finely divided catalytic agent such as nickel. Hydrogenation besides making oils solid at room temperature, causes them to become more stable and makes edible oils of those which, like fish oil, have been 3 Montgomery, Ward and Co, "Groceries" Dec. 1916, page 24 \& 25 4

Sears, Roebuck \& Co., "Your Grocery Store" Apr. 1917, page 41 5 Ward, Artemin, "The Grocers Incyclopedia." 
heretofore inedible. Fish oils are now hydrogenated extensively in Sweden and are said to be quite satisfactory. A drying oil upon being hydrogenated becomes a non-drying oil. The cost of the process is from 1 the to $2 \&$ per pound of fat. The nickel remaining in the fat after hydrogenizing has been found to amount to from 1 to $6.3 \mathrm{mg}$ per kilogram of fat. The wholesomeness of fats containing nickel will be discussed later under the subject of the digestibility of fats.

Corn 011

Another vegetable oil whichis now becoming important for food purposes is corn oil. It is obtained either by expressing the fat from the embryo which has been removed before the corn is used in the manufacture of starch and corn meal, or by recovering the fat from the residue of fermemtation vato after alcohol has been produced. The former process yields a golden yellow fat, whereas the latter gives a reddish brown oil.

olive 0il.

An oil which has been in use since ancient times is olive oil. It is prepared from the pericarp of the olive fruit. It differs greatly in quality according to the method by which it is obtained. The olives intended for oil

6

Suseman, "Are the Hardened Fats Bitable Food for Man?" Arch. Hyg. 84: 121-145.

7 " Arch. Hys. 84: 121-145.

Burtt-Davy, "Maize, Its History, Cultivation, Handling and 8 Uses." pages 696 and 785 .

Lewkowitsch, "Chem. Tech, and Analysis of 0ils, Fats and Waxes," Vol II, page 338 . 
production are gathered just before the fruit is ripe for at this stage it produces the best quality of oil. The fleshy part of the best olives contains 40 to $60 \%$ of oil. though in some fruit it runs as low as 10\%. California olives yield a must smaller quantity of oil than the best European varities. The very finest oils are obtained by pressing the fruit cold without breaking the kernels. This yields an oil which is called virgin oil. The residue is again pressed after adding water and again after the addition of hot water producing in both cases oils of inferior qualities. The best edible oil contains practically no free fatty acids, has almost no odor, and is pale yellow in color. The color of the various qualities of olive oil ranges from water white to golden or greenish yellows. A green color is very pronounced in low class oils. Olive oil has nearly the lowest iodine absorption number of any oil. It runs from 81.6 to 84.5 . Other oils which might be used for the adulteration of the olive oil would raise the iodine number and hence this gives a means of detecting the preaence of an adulterating oil.

peanut 011.

The industry of producing oil from peanut in the United States bids fair to reach 1mportant proportions since the cost of cotton seed has increased. Heretofore the manufacture of this oil in this country has been very slight because the peanuts have been disposed of in other channels of trade 
at a price higher than could be paid by the oil manufactures. Up to the present time considerable peanut oil has been imported from furope, the imports in 1914 exceeding one million gallons. In Furope the high grade peanut oil is made from peanuts which have been cleaned, shelled, blanched and degermed before being pressed. The first pressing is made without heating the material. After the first pressing the cake is reground and heated for a second and sometimes for a third pressing. The best grades of peanut oil are used for salad oils while the second grade oil goes into the manufacture of margarine.

Lard. ${ }^{10}$

One of the most commonly used animal fats is that obtained from hogs. Lard is defined as the fat taken from any and every part of the hog. The Chicago Board of Trade indicates the following brands of edible lard:

(a) Neutral lard No.1; (b) Neutral lard No.2; (c) Leaf lard; (d) Choice Kettle rendered lard; (e) Prime steam 1 ard.

When the carcass of the hog is cut up the leaf is taken out, chopped, washed with iced water, and then heated to 40 or 50 degrees $C$. The result yields neutral lard No. 1, which is used almost exclusively in the manufacture of oleomargarine. The fat from the back produces neutral lard No. 2, which is used chiefly by the confectioner and biscuit maker. Leaf lard is obtained from the residue from 
neutral lard No. I by subjecting it to steam heat under pressure and from the lard removed from the internal fat of the abdomen. Choice kettle rendered lard, rendered by stean heat, comes from the residue from neutral lard No. 2. Standard prime steam lard is obtained from all other parts of the hog that will yield lard. The melting points of lard vary from 27 degrees C. to 49 degrees, depending upon the location of the fat in the body,--the more exposed parts of the body yielding fats of lower melfing points.

\section{1 \\ Beef Fat}

Beef fat is harder than lard because of the presence of a larger proportion of stearin. The hardness of the fat varies with the part of the body from which it is obtained, the kidney fat being harder than the back fat, etc. Because of the high melting point of beef fat and its sometimes pronounced flavor it has been less generally used than lard for shortening. However, finely chopped, unrendered suet is used in shortening some dishes and in some countries arippings from the cooked beef or sometimes simply rendered beef ouet is used in place of butter to eat on bread. Beef olein is used in the manufacture of oleomargarine.

\section{1}

Mutton Fat.

Mutton is mach less extensively used in cooking than either lard or beef fat. probably because of the mutton flavor which is unpleasant to many people, and because of

11

Holmes and Lang, "Fats and their Economical Use in the Home" - Farmers Bullet in 469. 
the hardness of the fat. It is sometimes mixed with the softer fats and used for shortening and frying.

11

Butter.

Butter is the most popular and widely used of all fats in the United States. It is estimated that from 17 to 18 pounds per person are consumed yearly. Butter contains approximately $82.5 \%$ of fat. The characteristic flavor is due to the presence of a small proportion of low glycerides of fatty acids myristin, butyrin, etc., and to the presence of some casein and its attendant flavors. The color of butter varies with the food material eaten by the cow, the yellow being deeper in summer when green food is eaten. Butter of inferior quality is frequently treated by a commercial process which removes objectionable flavors so that it is then marketed as renovated butter. In the process used the butter is melted, and air is blown through it until the volatile flavor is carried away, after which the fat is emulsified with sour milk and worked like ordinary butter. Rendered butter called "ghee" in India is prepared by melting the butter and allowing the casein and water to settle out and be discarded. Its keeping qualities are superior to those of butter.

Butter substitutes.

Because of the high cost of bitter the manufacture of butter substitlites has found a place in industry. As early as 1870 the French Chemist Mi. Lege-Mouries had discovered 
a method of preparing a butter substitute. He heated finely minced beef suet with water, carbonate of potash, and fresh sheep's stomachs cut up into small fragments. The pepsin of the sheep's stomach separated the fat of the suet from the cellular tissue. He pressed the fat when cool, separating it into stearin and olein. To the soft fat he added milk and churned it, producing a fat having a flavor similar to that of butter. This method has been used with various imporvements until today the industry has reached immonse proportions. The principal fats used in the United States for the manufacture of butter substitutes are oleo,oil, neutral lard, cotton seed oil and other oils. Whatever fat is used it must be carefully prepared in order that it shall have no marked taste or odor. The fats are mixed in such proportions as will give a product having a melting point very close to that of butter. The proportions of milk, cream, or real butter used with the other fats determine the grade of the substitute produced since the higher the proportion of butter in the mixture the greater the cost of production. The grainy texture of butter is obtained in oleomargarine by forcing it in $f$ ine particles into iced water and working the chilled particles while cold. The proportion of water and casein in the butter substitute is approximately the same as is in butter 12

In the United States the oleomargarine industry has been reglilated by the Federal Laws of August 1880 and 
May, 1906. The latter law taxes uncolored oleomargarine

- 2.5 cents and colored oleomargarine 10 cents per pound. This prevents the use of artificial coloring matter in oleomargarine made and used in this country. For this reason manufacture's of oleomargarine prefer fats having naturally a yellow color. The oleomargarine now sold is yellowish though not nearly so yellow as'ordinary butter.

THE PRICES OF EDIBLE FATS.

The fats which have been discussed vary considerably in cost. Since this is an important item in the selection of a fat for food we shall give the prices of the fats on the local market noting the cost in small quantities and in larger quantities, the change in cost as food prices have changed, and the relative cost of the various kinds and brands of fats: 
Name of Fat. Wt. of Can Cost of Can. Cost per 1b. Increase (net) 1b. 1915-1917 1915-1917 in cost per $1 b$.

\begin{tabular}{|c|c|c|c|c|c|c|c|c|c|}
\hline Creamery butter & 1 & $I b$ & & $\$$ & .35 & $\$ .45$ & $\$ .35$ & .45 & .10 \\
\hline ol eorargarine & 1 & $1 b$ & & & .25 & .30 & .25 & .30 & .05 \\
\hline $\begin{array}{l}\text { Oleomargarine } \\
\text { (different qual }\end{array}$ & $\begin{array}{c}5 \\
\text { Lity }\end{array}$ & 1b & & & & .75 & & .15 & \\
\hline Suet, $90 \%$ fat & 4 & $1 b$ & & & .25 & .40 & $.06 \frac{2}{4}$ & .10 & $.03 \frac{3}{4}$ \\
\hline Lard (bulk) & 1 & $1 b$ & & & .15 & .25 & .15 & .25 & .10 \\
\hline Iard (in $\operatorname{cans})$ & 2 & $1 \mathrm{bl}$ & 100 & $o z$ & .50 & .75 & .21 & .286 & .076 \\
\hline Lard " " & 4 & $"$ & $8 "$ & & .85 & 1.25 & .188 & .277 & .089 \\
\hline Lard " " & 9 & $"$ & $6 "$ & $"$ & 1.50 & 2.40 & .174 & .26 & .086 \\
\hline Lard " " & 46 & ": & $12 "$ & $"$ & & 10.90 & & .232 & \\
\hline Crisco & 1 & $"$ & 8 & $"$ & .25 & .35 & .167 & .233 & .066 \\
\hline Crieco & 3 & $"$ & $1 "$ & $"$ & .50 & .70 & .163 & .228 & .065 \\
\hline Crisco & 6 & $"$ & 3 & $"$ & 1.00 & 2.40 & .161 & .226 & .065 \\
\hline Crisco & 9 & $"$ & 5 & $"$ & 1.50 & 2.10 & .16 & .204 & .044 \\
\hline Compound & 1 & $"$ & & & .15 & .20 & .15 & .20 & .05 \\
\hline Wesson Oil & 1 & $p t$ & 3 & " & .30 & .35 & .252 & .294 & .042 \\
\hline Wesson Oil & 1 & $q t$ & 7 & $"$ & .50 & .60 & .205 & .246 & .141 \\
\hline Wesson Oil & 2 & $"$ & $14^{\prime}$ & $"$ & 1.00 & 1.20 & .205 & .246 & .041 \\
\hline Corn Oil & & & $5 \frac{1}{2}$ & $"$ & .12 & .15 & .34 & .42 & .08 \\
\hline Cornoil & & & $16^{\prime \prime}$ & " & .25 & .30 & .25 & .30 & .05 \\
\hline Corn Oil & 1 & gal: & Lion & & 1.50 & 1.75 & .187 & .22 & .033 \\
\hline olive Oil & & & $4^{\prime}$ & $"$ & .25 & .25 & 1.00 & 1.00 & .00 \\
\hline $\begin{array}{l}\text { Olive Oil } \\
\text { (Monarch) }\end{array}$ & & & $8 "$ & " & .35 & .45 & .70 & .90 & .20 \\
\hline $\begin{array}{l}\text { Olive Oil } \\
\text { (Monarch) }\end{array}$ & & & $16^{\prime \prime}$ & " & .65 & .85 & .65 & .85 & .20 \\
\hline $\begin{array}{l}\text { Olive oil } \\
\text { (Bertoli) }\end{array}$ & & & $16^{\prime}$ & $"$ & .45 & .50 & .45 & .50 & .05 \\
\hline $\begin{array}{l}\text { olive oil } \\
\text { (Bertoli) }\end{array}$ & 1 & $q t$ & & & .85 & .95 & .425 & .475 & .05 \\
\hline $\begin{array}{l}\text { Olive oif } \\
\text { (Bertoli) }\end{array}$ & 1 & gal & $110 n$ & & 2.75 & 3.25 & .344 & .405 & .051 \\
\hline
\end{tabular}


This table shows a fluctuation in price attending the war conditions, a difference in cost due to the size of the container, and a difference in cost of the various fats. It is worth noting that one brand of olive oil increased in cost .20 cents per pound while the other brand increased only .05 cents per pound, that olive oil in 4 ounce bottles costs $\$ 1.00$ for 16 ounces while the same oil bought in 16 ounce cans cost in November, 1915, .65 cents and in March, 1917, \$.85. The oils run in cost from corn oil at \$.187 to $\$ .34$ a pint to Wesson 0 il at $\$ .246$ to $\$ .294$ and olive 0 il $\$ .405$ to $\$ 1.00$.

The solid fats ranked according to cost run:--beef ouet or mutton tallow $\$ .10$ a pound, oleomargarine bought through a purchasing agent for a large cafeteria \$0.15, compound $\$ 0.20$, cottolene $\$ 0.215$, crisco $\$ 0.204$ to $\$ 0.233$, lard $\$ 0.232$ to $\$ 0.286$, oleomargarine in pound wrappers $\$ 0.30$, creamery butter $\$ 0.45$.

Therefore we see that the cost is influenced by the quantity of fat bought at one time, by the conditions of food prices in general, and by the kind of fat bought. One of the questions which this paper shall investigate further is the comparative value of these various fats in different cooking processes. We can make good cake from oleomargarine at $\$ 0.15$ to $\$ 0.30$, or crisco at $\$ 0.20$, or oil at $\$ 0.18$. This is certainly much cheaper than using butter when it costs 45 or 50 a pound. We can $\mathrm{mix}$ a fat of beef suet at $12 \not \varnothing$ a pound when rendered and oil at $18 \not$ yielding a compound costing $14 \%$ which is even cheaper than lard at 25\%. Is it as satisfactory? These questions will be 
taken up in connection with the experimental work.

RANCIDITY OF FATS.

In addition to our acquaintance with various fats

which are available and the relative cost, we must congider the conditions which influence their keeping qualities and $f$ ind what can be done to prevent the rancidity of fat and in case this occurs to determine whether the condition can be so remedied as to make the fat available for food.

\section{Nature of Rancidity.}

By the rancidity of a fat we mean a condition which includes a number of changes in the composition of the fat and is attended by a strong penetrating odor and a disagreeable taste. The fat has a higher acetyl value and develop more free fatty acid than fat which is not rancid. The rancidity does not however run parallel with the acidity, for the presence of small quanitities of free fatty acids impart a slight not unpleasant flavor to fats and oils while completely neutral fats have an insipid taste. Nagel who worked upon the rancidity of fats reports that he found In them: free fatty acids, hydroxy acids of the fatty acid series, lactones and anhydrides of fatty acids, alcoholB, esters of fatty acids, aldehydes, acetals and terpens.

\section{Causes of Rancidity.}

Exposure to the atmosphere causes fats and oils to 
undergo changes toward rancidity. The extent of these changes vary in a marked degree with the chemical composition of the glycerides. The greater the proportion of unsaturated fatty acids in the fats the greater their power to absorb oxygen. In the presence of moisture, enzymes are capable of hydrolizing fats. Smith ${ }^{14}$ (1916) says that rancidity ay be induced by microorganisms if there is a slight amount of protein present. Wagner, Walker and 15

oesterman sealed samples of various fats and oils in flasks and after filling the small air space above the surface of fat with nitrogen, they exposed it to the sun for two years. When the samples were examined there was found an increase in the acidity, they had become blanched, and had acquired a disagreeable taste and rancid odor. Hence the conclusion was drawn that light alone can cause fat to become rancid.

The effect of the kind of container upon the composi16 tion of a fat was investigated by J. A. Bmery . He showed that where an increase in the acid content of a fat or oil was noted there was an increase in the solvent action of the oil for metals, particularly where other favorable conditions such as heat moisture and air were present. Cotton seed oil showed little or no effect. Zinc, copper and lead were somewhat readily acted upon. Aluminum, iron, 14 15

Smith. "The Rancidity of Fats," Pharm. Jour 95(1915)page 4-5. Wagner, Walker, and Oestermann," The Influence of Light upon Fats under the Absolute Fxclusion of Air."- $Z$. Nahr. und 16 Genussm. 25(1913) page 704.

Fmery,"The Use of Metallic Containers for Edible Fats and 0 il ${ }^{\prime \prime}$ Report. Bur. Animal Ind.(1909), page 265-282 
and tin had a high resisting power.

\section{Prevention.}

In the light of these experiments we can see that fats willkeep best where made as free as possible from moisture, and kept from exposure to the light and atmosphere, in containers such as aluminum, iron or tin, which will not be acted upon by the free acids in the fat.

\section{Treatment of Rancid Fats.}

Once fats have become rancid our problem becomes one of making them again fit for food. The method of renovating butter by blowing air thru the fat until the volatile acids have been removed, has already been mentioned. Distilla17 tion with steam will remove the alcohols and esters of the fatty acids, and some of the aldehydes and lactones. Hot water will remove the soluble fatty acids. A solution of potassium pernanganate will oxidize the aldehydes and ketones. The fatty acids must be removed by being neutralized or absorbed by some substance which can be easily separated from the fat. Sodium carbonate or sodium hydroxide will neutralize the fatty acids, but they cause the formation of emulsions which are very hard to remove. The substance used must form a precipitate in the mixture so that it may be filtered out of the fat. Soluble glass is suggested by Nagel as satisfactory for this purpose. Home methods for correcting the rancidity of fats are recommended 18 by Holmes and Lang . They also give suggestions for 17 18

18 Nagel, "Rancidity and Fats"-Amer. Chem. Jour.23:173-176. Holmes and Lang, "Fats and their Economical Use in the Home", Farmers Bulletin 469. 
clarifying fats which have been used in cooking. They recommend that undesirable odors and flavors be removed by the use of a good grade of charcoal. To each pound of chopped unrondered fat add 12 pieces of clean hardwood charcoal about the size of a walnut and allow the charcoal to remain in the fat while rendering and for about two hours. The fat may then be strained through flannel. This method also has a bleaching effect. For clarifying fats water may be added in equal volume, the fat and water heated for a short time, and the mixture allowed to cool after which the layer of fat may be removed. Rendering fat with sour milk gives good results in modifying odors and flavors

\section{THE COOKING OF FATS.}

A few experiments have been made which throw some light upon the use of fats in cooking.

The Use In Frying.

In frying, fats are used as a medium for conducting heat to foods. The high temperature to which they are heated and the change in their appearance after being used for frying makes it seem probable that they may undergo chemical change. An investigation of the effect of heat upon some fats is reported by Fulmer and Manchester . On heating cottonseed oil between the temperature of 180 degrees to 270 degrees C. they found that there is a gradual and slight

Fulmer and Manchester, "Changes in the Character of Fats During the Process of Cooking," Jour. of Amer. Chem. Soc. 30 (1903) page 1477. 
increase in the refractive index, a small decrease in the iodine value and above 220 degreen C. akdenided increase in acidity. The saponification value appears to change but little. The meaning of some of these results may be interpreted in the light of another experiment which shows the relation of acidity of the fat and smoking temperature.

The temperature at which the fat smokes is important when it is to be used for frying since a fat whoh smokes at a temperature below that used for frying (185 degrees C. to 190 degrees C.) is disagreeable to work with, makes the food less appetizing and perhaps less wholesome. The occurrence of acrolin when fat is heated to the point of decomposition is said to make the fat irritating to the mucous membrane of the stomach. On this account the tempergure at which a fat decomposes is important in determining its usefulness as a rnedium of frying.

Work done upon the smoking temperatures of $f$ ats is re20 ported by Blunt and Feeney - The temperature at which the fat gave off visible fumes was considered the smoking temperature. They used for the first part of the experiment No. 4 evaporating dishes, the upper surface of the fat having a diameter of about $3 \frac{3}{4}$ inches. To get the relation of the acidity to the smoking temperature the acidity of the fat used was determined. $\mathrm{N} / 20 \mathrm{NaOH}$ was used, and 15 grams of the sample of fat. The results are shown in the table given:--

\section{0}

Blunt and Feeney, The Smoking Temp. of Edible Fats, Jour. of Home Econ. 7 (1915) pages 535-541. 
Kind of Fat.

Cottonseed oil (Wesson)

Snoudrift

Crisco

Leaf lard

Butter fat

Leaf lard(heated 5 hrs)

Bulk lard

A much used lard

Olive oil

Peanut oil $\bar{I}$

Peanut oil $\overline{I I}$

Cocoanut oil
Smoking Temp. degrees Centigrade

Free acid. per cent.

\section{3}

0.07

232

0.06

231

0.13

221

0.15

208

0.28

207

0.34

194

0.51

190

0.61

175

0.92

162

1.10

149

1.64

136

1.90

In order to further prove the relation of acidity and smoking temperature they added free fatty acid to a fat and found that the smoking temperature wa lowered accordingly, and they neutralized the fatty acid in olive oil, extracted the fat, and found that the smoking temperature was raised 59 degrees above the original oil.

They report that the surface exposed has an effect upon the temperature at which the fat smokes. This variation is shown in the following table:-- 
Name of Fat.

Crisco

Bulk lard

Wuch used lard

Olive oil
Smoking Temperature.

Diameter of surface exposed
$3 \frac{1}{4}$ inches 7 inches $10 \frac{1}{4}$ inches

231 degrees C. 220 de. C. 206 De. C.

$\begin{array}{llllllll}194 & " & \text { " } & 183 & \text { " } & 169 & \text { " " } \\ 190 & " & \text { " } & 180 & \text { " } & & & \\ 175 & \text { " } & 161 & \text { " } & & & & \end{array}$

Samples of olive oil and of cottonseed oil were heated in test tubes. The temperature was raised to 360 degrees without smoke becoming visible, but when the thermometers were withdrawn the oil clinging to them smoked profusely; The presence of finely divided foreign substance lowered the smoking temperature of some fats tested. Flour added to cottonseed oil (smoking temperature 238 degrees) lowered the temperature to he limit of 133 degrees. After the fat was filtered the smoking temperature remained lower than the original. The three factors therefore which the investigations found to influence the smoking temperature are the acidity, the extent of the exposed fat surface, and the presence of finely divided foreign substances. In connection with the smoking temperature of fats it is interesting to note the work of Lowenstein and Vollertsen who submit experimental data showing that the presenceof free fatty acid depresses the flash and fire points of animal fats and oils, the amount of depression varying witn the amount of free fatty acid 21 Lowenste in and Vollertsen," The Effect of Free Fatty Acids, upon the Flash and Fire Points of Animal Fats and Oils,"Jour. of Indus. and eng. Chem. $7(1915)$ No.10, page 850 . 


\section{present.}

Some preliminary experiments upon the quantity of fat when are wed absorbed by different fats $n_{n}$ in deep frying at different tem22

peratures, were carried on by Holmes and Lang . Doughnuts were prepared from flour, egg, milk, sugar and baking powder and portions of uniform size and shape were fried for definite periods of time in beef fat, lard, cottonseed oil, cocoanut fat and peanut oil at a number of different temperatures. They found that there was a definite temperature for each fat at which the doughnut soaked up the omallest quantity of fat and were most satisfactory in texture. This temperature was about 182 degrees C. for beef fat, 176 degrees C. for lard and 199 degrees C. for the vegetable oils. Subsequent chemical analysis of the doughnuts showed that if this temperature were lowered 11 degrees C. for the animal fats and 25 degrees $C$. for the vegetable fats. the quantity of fat absorbed by the doughnuts was increased approximately 25\%. It was recommended that for successful deep frying, vegetable fats ahould be heated from 17 degrees to 23 degrees C. higher than animal fats.

\section{Fats In Pastry.}

I. Changes Due to Cooking.

The changes occurring in fats during the process of cooking with flour mixtures is shown by experiments made with 23

pastry by Masters and Smith - They used butter fat and 22

Holmes and Lang, "Fats and their Economical Use in the Home" 23 Farmers Bulletin 469.

Masters and Smith, "The Changes in the Character of Fata During the process of Cooking." Analyst. 39(1914) No.461 
cottonseed oil. The proportions of the pastries were either (a) flour 200 grains, oil 60 grams and water 50 grains, or (b) flour 200 grains, butter fat 100 grams and water 80 gram. No baking powder was used. The flour used contained $1.2 \%$ of fat. Control experiments were carried out by mixing flour and fat in the same proportions as in the pastry but without water. The pastries were cooked for different lengths of time and were of different thicknesses. The result show a decrease in the iodine value, and increase in the acetylvalue and refractive index and a slight increase in the acidity. The conclusion is drawn that the changes in a fat cooked normally are slight unless the food is considerably overcooked. Miss Wallace who worked upon the most favorable témperatures for baking pastry found the constants of fats cooked in pastry and concluded that a temperature of 250 degrees C. which she used did not result in the decompositionof lard.

2. The Effect of the Temperature used in Mixing. Frequently suggestions have been made that pastry might be mixed with warm water. An investigation of this method of mixing in pastry conducted by Miss Taylor led to the following conclusion:

"1. Good pastry may be made with warm water. 2. Warm water gives a paste with a mealy feel.

24 Wallace, "The Most Favorable Temperatures for Cooking Some Typical Foods." M. U. Thesis 1915, pages 75-84. 25

Tavlor, "Cold v8. Warm Water in Pastry." Jour. of Home Econ. 8 (1916) page 189. 
3. More time is required for manipulation when warm water is used.

4. More flour is required on the board when warm vather is used.

5. When exposed to the atmosphere at room temperature the warm water paste absorbe moisture more readily than does cold water paste.

6.. Cold water is more desirable than warm water for pastry."

The temperature of the fat used in biscuits was the 26 subject of work done by Miss Watson . She tried using butter cold by rubbing and cutting it into elour, with the result that the biscuits were spongy, of good texture and quite tender. When the butter wasmelted and mixed in, the outward appearance was equally as good but the texture was inferior and the crumb more tough. Then the two methods of mixing were tried with cookies,little difference was noted in samples after baking, one being as good as the other.

3. Comparison of Recipes for Pastry.

The effect of folding fat with pastry rather than cutting 27

it in was shown by Miss Wallace to cause a greater evaporation of water and a lighter pastry. She found that as the fat was increased in pastry up to a maximum of $3 \mathrm{~T}$ of lard per half cup of flour the lightness was increased. A variation in the amount of water used showed that the pastry containing $30 \%$ of water was lighter than that containing

Wataon, "Mixing Fat with Dough," Farmers Bul. 360 page 32. 27

Wallace, Whe Most Favorable Temperature for Cooking Some Typical Foods." M.U. Thesis 1915, pages 75-84. 
I5\%. She found that the I5\% of water in butter caused pastry to be lighter than that made with lard whoh contained no water. The temperature of the inside of the pastry was found to be higher after a given length of time when the fat was folded in.

4. Influence of Fat on Texture and Flavor.

In regard to fats in cakemaking, we may not.e the bon28

clusion of Miss Milis says that "cake made of a good grade of cottonseed oil tastes and smezls slightly of the oil when the cake is warm, but when it is cold the flavor is nutty and pleasing, the cake finegrained, light and soft, due to the use of soft fat, and the keeping quality is excellent." Cottonseed cooking oil could then be obtained for \$I.25 a gallon and, while it is more expensive now, it is still economical for use in place of butter: Chicken fat is recommended as an excellent substitute for butter.

THE DIGESTIBILITY OF FATS.

The substitution of one fat for another will meet witr little favor if we find that they are not equally wholesome and digestible. There are many beliefs current as to the effect of fats on digestion. We often hear that lard is Indigestible, and that pancaires are injurious because they are so greasy, and that pastry is too rich in fat to be healthful. We are aware of the presence of nickel in the hydrogenated fats and raise the question of 1 ts effect upon the value of the fat. Some people report disturbances

Milis, "Making Cake" Part I, Cornell Reading Courses. 
of digestion after eating beef fat or mutton fat. There are experiments reported which help to settle some of these points.

Influence of Melting points.

The relative digestibility of lard, beef slet, cottonseed oil, olive oil, peanut oil and crude cottonseed oil with mice and guinea pigs as slibjects is reported by J. F. 28.

Moore He found the coefficient of digestibility to run as follows:-

Hice Guinea Pigs.

$\begin{array}{ccc}\text { Cottonseed oil, light } 96.19 \% & 93.37 \% \\ " \text { " } & \text { " heavy } & 90.47 \\ \text { Soft lard } & & 89.93 \\ \text { Olive oil } & 97.70 & 88.78 \\ \text { Peanut oil } & & 88.81 \\ \text { Corn oil } & & 85.77 \\ \text { Hard lard } & & 86.47 \\ \text { Beef suet } & & 73.88 \\ \end{array}$

The influence of the melting point of non-emulsified fats on the rate of leaving the stomach is discussed by A. Von Fejer. He concludes that the lighter the melting point and tine greater the viscosity of a fat the longer

28

Moore, "Relative Digestibility of Some Edible Fats and Oils." Ark. Bul. No. 78, pages 33-41.

29

Fejer, "The Influence of the lielting Point of Non-emulsified Fats on the Rate of Leaving the Stomach." Biochem. Ztochr. 53(1913) No. 1-2 pages 168-178. 
it will remain in the stomach. The non-emalsified fats leave the stomach more slowly than fat emulsions. 30

Langworthy and Holmes made a study of the digestibility of lard, beef fat, mutton fat and butter. The fat was incorporated in a caramel blancmange and fed to the subjecta with a simple mixed diet. The flavor of the fat was concealed. Each test period included 9 meals. They found that all the fats lised were well assimilated. Butter showed the highest coefficient of digestibility (97\%) while mutton fat fell to $88 \%$. The average amount of fat eaten per oubject per day was lard 90 grams, or beef fat 100 grams or mutton fat 53 grains or butter 100 grams. The values for the digestibility of the carbohydrate content in the diets were with lard $96 \%$, beef fat $97 \%$, mutton fat $97 \%$ and butter $96 \%$. In the ordinary mixed diet the average value of carbohydrate digestibility is $97 \%$. Therefore the fat diet did not lower the digestibility of the starch.

The melting points of the fats ranged from 32 degrees C. for butter fat to 50 degrees C. for mutton fat. The experiments seemed to prove that the fats of low melting points are more completely assimilated than those of high melting point. The fact that in the beef fat experiments, the subjects experienced a laxative condition leads to the ouggestion that the tolerance for beef fat is lower than for other fats.

30 Iangworthy and Holmes. "The Digestibility of Some Animal Fats." Farmers Bulletin 310(1915) 
Absorption of Different Kinds of Fats.

31

Gerlach (1907) compared the assimilation of animal and vegetable fat by using butter and a commercial butter substitute prepared from cocoanut oil. He observed the effect of the diet upon himself for a long period of time and as a result found no difference in their digestibility. Kienzl compared the absorption of combinations of (1) margarine butter and schmalz, (2) butter and lard, (3) margarine butter and oleo, and (4) of butter and rendered butter and found the coefficient of digestibility to be respectively (1).95.6, (2) 97, (3) 95.7, (4) 96.6 .

The Digestibility of Hardened Fats.

The extensive use of hardened fats at present makes the question of their wholesomeness of interest. Thom s and Miiller compared the availability of the hardened vegetable oils with some of the more common animal fats and also with the same vegetable oils in the fluid condition. As a reoult of their feeding experiments upon animals and men they recommend that a fat ahould not be hardened to give a melting point of over 37 degrees C. body temperature. In practically every case, even if the digestibility of fats melting higher

31

Gerlach, "Assimilation of Animal and Vegetable Fats by Man." Ztschr. Diatet. u. Phys. Ther. 12(1907), page 102.

32

Kienz1. "Absorption of Several Kinds of Fat in the Intestinal Tract of Man." Oesterr. Chem. Ztg. I (1898) No. 6, pages 198-202.

33

Thomp and miller, "The Use of Hardened Fats for Food Purposes." Arch. Hyg. 84 (1915) No. 1 pages 54-77. 
than body temperature was not noticeably different from that of lower melting fats, there was noted a tallowy taste and intestinal disturbances such as usually attend the use of beef and mutton tallow. It is suggested that if the melting point of the fat is higher than 37 degrees C. a mixture may be prepared by the addition of a lower melting fat.

Süssman (1915) analyzed a number of samples of hardened sesame, peanut and cottonseed oils to determine the amount of metal present. They were found to contain respectively 1 to $1.1 \mathrm{mg} ; 1.6$ to $6.3 \mathrm{mg}$ and .07 to $.4 \mathrm{mg}$ of nickel per kilo of fat. Larger amounts of iron were detected but these were not regarded significant to the hygiene of feeding. In a series of feedine experiments with dogs, $2.8 \mathrm{much} a 8.75 \%$ of the body weight of hardened fat was eaten daily without noticeable disturbance. The amount of nickel present in the hardened fat was considered too small to produce any ill effects so that these fats were said to be in every way suitable for human food. 35

Lehmann came to a similar conclusion. He found that hardened fats made from peanut, cottonseed and sesame oils showed a nickel content of from .07 to $6.1 \mathrm{mg}$ per kilo. Feeding experiments with dogs led to the conclusion that $2 \mathrm{mg}$ of nickel per kilo of body weight is harmless. Therefore he said that hydrogenated fats contain inappreciable amounts of nickel so there is no objection to their use as foods. 34

Sïsoman, "Are the Hardened Fats Suitable Food for Man?" Arch. Hyg. 84: 121-145.

35

Lehmann, "Sre the Hardened Fats Suitable for Human Food?" Chem. Ztg. 38 (1914) No. 75, pages 798-799. 
An experiment interesting in connection with the digestibility of $f$ at is one carried out by Daniels and Strickler . It is generally thought that pastry is hard to digest, the reason sometimes offered being that the fat surrounds the starch grains, thus preventing the starch oplitting enzymes from acting on the grains. But when the pastry was examined microscopically after staining the ramples, the stained fat was shown distributed in masses. When the condition of the starch in pie crust is compared with starch in other foods it is found that pastry has the highest proportion of raw starch. Hence they attribute the disturbance sometimes caused by pie crust to insufficiently cooked 37

starch. Miss Daniels has been conducting an experiment upon the effect of acrolin upon digestion. The points considered included the (1) Determination of the amount of acrolin in various fried foods quantitatively.

(2) Methods of determining acroyjin.

(3) Influence of acrolein on digestion.

(4) Influence of acrolkin on growth.

(5) Influence of superheated fat on acrolein.

(6) Influence of superheated fat on digestion.

(7) Influence of superheated fat on growth.

(8) Influence on digestion of different methods of combining fats in various suaces.

So far as they were able to determine, acrolin, although

36

Daniels and Strickler, "A Comparison of the Digestibility of Starch." Jour. of Home Econ. 9(1917).

37 pages $109-114$.

Daniels, The University of Wisconsin, College of Ag., Madison, Wisconsin, 1917. 
disagreeable if taken in large quantities does not have an untoward influence on digestion, nor did superheated fat effect the people under investigation, unless a larger proportion of $f$ at was taken than they could easily digest. The same effects were produced with unheated fat in large quantities. Frogs given large doses of acrolin were not noticeably injured by it. The contention is that fat in large quantities is the disturbing element in digestion more than superheated fat. The question is still under investigation

SUMMARY OF IITERATURE.

Available Fats.

I. The avilable fats for cooking and food purposes include cottonseed 0 il and its products, corn oil, sesame oil, olive oil, peanut oil, butter fat, lard, beef fat and mutton fat.

2. Cottonseed oil which has proved to be a cheap and satisfactory source of fat for food appears upon the market under various trade names.

3. It is sold in the form of salad oil, and mixed with solid fats as lard substitutes, and as solid fat made solid by means of a process of adding hydrogen to the fat molecule.

4. Hydrogenation of oils makes them solid at room temperature, causes them to become more stable. and makẹs edible oils of those oils which,like fish oil, have heretofore been inedible.

5. Corn and peanuts are becoming important sources of 
table oils.

6.

Olive oil is found upon the market in many grades and under many trade names.

7. Lard is divided by the packing houses into five grades.

8. Beef and mutton fat beine harder than the other fats and sometimes having a strong flavor have not been extensively used for cooking fats.

9. Because of the cost of producing butter, a butter substitute has been put upon the market. It is made of various kinds of fats mixed with some milk or cream to give it the butter flavor.

\section{Prices of Fats.}

A comparison of the cost of edible fats reveals the fact that the cost is influenced by

I. The kind of $f$ at.

2. The trade name.

3. The size of the package purchased.

4. The general market conditions.

5. The proportion of water and other oubstance sold with the fat.

\section{Rancidity.}

I. Fats will keep best when made as free as possible from noisture and kept from exposure to light and air.

2. Containers made of zinc, copper, and lead are acted upon by acids in $f$ at $s$ and hence are inferior for containers. 
blowing air thru them, distillation with steam, and by use of various chemicals.

4.

Methods which are suggested for correcting the rancidity of fats in the home are, the use of hot water, rendering with sour milk; or charcoal, or fullers earth.

\section{The Cooking of Fats.}

I.

süperheating fats causes a decided increase in acidity.

2. The higher the acidity of a fat the lower the temperature at which it smokes.

3. The smoking temperature is said to be influenced al so by the extent of the fat surface exposed, and by the presence of finely divided foreign substances in the fat.

The quantity of fat absorbed in frying is influenced by the temperature of the fat and by the kind of fat used.

Changes in a fat cooked normally in pastry are slight.

6.

Pastry may be mixed satisfactorily with warm water, but cold water is more desirable.

7. The lightness of pastry is influenced by the method of mixing, the proportion of fat, and the quantity of water used.

8. Cottonseed oil used in cakes makes a product which is finegrained, light and soft and of pleasing flavor. 
The Digestion of Fats.

I. Fats of low melting point are nore completely assinilated than those of high nelting point.

2. Animal fat (butter) and vegetable fat (a butter substitute) are equally digestible.

3. Hardened fats should not be hardened to give a melting point above the body temperature.

4. The nickel in hardened fats is inappreciable in amount so there is no objection to their use as foods. 5. Disturbamces of digestion attributed to fats in pastry may be due to the presence of raw starch.

6. It is suggested that fat in large quantities may be the disturbing element in digestion that has been considered due to superheating fat and the production of acrolin. This question is still under investigation. 


\section{STATEMENT OF PROBLEM}

The investigations recorded in this paper were undertaken for the purpose of supplementing investigations reported from other sources in order to get a clearer understanding of:

1. The Use of Fats in Frying.

a. The smoking temperature.

b. The absorption of fat by food.

2. The Use of Fats in Pastry.

a. Changes in the composition of fat.

b. The possibility of incomplete extraction.

e. The effect of various fats upon the texture, flavor, and lightness of pastry.

3. The Use of Different Fats in Cakemaking.

a. Effect on flavor, texture, and lightness.

b. Difference in $\cos t$.

4. The Handing of Fats in the Home.'

a. The removal of strong flavor.

b. Decreasing the melting point.

c. Removing rancidity.

Use in Frying.

The Smoking Temperatures - The relation of smoking temperature to acidity, to surface exposed, and to the presence of foreign substance was investigated by Blunt and Feeney as reported previously in this paper. 38.

Blunt and Feeney. "The Smoking Temperature of Edible Fats" Jour. of Home Econ. 7(1915) pp. 535-547 
It was thought desirable to get the smoking temperature of some fats ot her than those reported, so oleomargarine, compound, corn oll and a cotton seed salad oll were investigated besides repeating the work upon some of the fats which Blunt and Feeney used. The repetition of some fats which they used, served to check this work with their report. The effect of change in the size of the surface exposed was observed, as was also the effect of changing the acidity of the fat and the 011, and the temperature at which a fat begun to smoke was compared with that at which it ceased when cooled.

The Absorption of Fat in Frying - The statement made by 39

Holmes and Lang that vegetable fats should be heated from $30^{\circ}$ to $40^{\circ} \mathrm{F}$. higher than animal fats suggested the questio: of whether this wou ta be true of vegetable fats in general or if the solid vegetable fats might be absorbed less extensively than the vegetable oils. Accordingly doughnuts were fried in an animal fat--lard,-a vegetable oll--wesson oil,-and a vegetable hydrogenated fat--crisco. The doughnuts were fried at different temperatures and the quantity of fat absorbed observed.

The Use of Fats in Pastry.

The Changes oecurring in Fats Cooked in Pastry - The work done by Masters and Smith upon the changes occurring 39

Holmes and Lang "Fats and Their Eeonomical Use in the Homen. Farmers' Bulletin 469. 
in fats when cooked in pastry has been discussed previously in this paper. For the sake of verifying their results upon a different fat the changes occurring in the lodine number and saponification number of oleomargarine when used in pastry were worked out.

A statement made by M. Weibull 40 that fat was retained by the starch in bread so that it could not be thoroughly extracted by ether, suggested that probably the same condition might maintain in the case pf pastry. This might materially affect the results obtained upon the constants of the fats extracted from the pastry. Therefore an experiment was made in which samples of oleomargarine were extracted from raw and from cooked pastry in order to compare the quantity which could be extracted from each.

The substitution of one fat or oil for another in making pastry brings up the question of the change which it will make in the lightness, texture and flavor of the product. This : . to an experiment in which oqual quantities of various fats and olls were used with the same quantities of flour and the resulting erusts compared.

The general habit of requiring butter for cakemaking and the mistrust with which the substitution of cheaper fats is re garded led to an experiment in which various other fats wore used while the other ingredients of the cakes and the methous of mixing and baking were kept as nearly constant as possible. 40

Welbull, M. SvenskkemiskTiaskrift No. 5, 1892. Abs. in Exp. Sta. Rec. Vol. V, p. 520. 
The relative molsture, texture and flavor of the cakes was observed, and conclusions drawn as to the possibility of substituting cheaper fats and oils for butter in oakemaking.

Handling of Fats in the Home.

Removal of Strong Flavor - The production of mutton is less expensive than the production of beef or pork but the use of matton fat has been very greatly limited by its strorg flavor and 1ts hardness. This paper records the results of various methods used for removing this strong flavor. Sinee one of the easlest places for recognizing a pecullar flavor is in cake the mutton fats were combined in cakes and the flavor of the eake observed.

Removing Rancidity - In the ovent that fats in the home have become rancid or have absorbed disagreeable flavors, the removal of the objectionable features becomes important. A number of suggestions have been found which might be used in the home. These suggestions were tried in the laboratory and their relative conventence and efficieney compared. 
RECORD OF EXPEERIMENTAL WORK

The Use of Fats in Frying.

The Smoking Temperature in Frying

Purpose of Experiment

To determine:

1. The temperature at which the fats and oils under observation showed first signs of smoking.

2. The temperature at which the smoking stopped when cooled.

3. Relation of proportion of surface exposed to the smoking temperature.

4. Relation of acidity to smoking temperature.

a. Natural acidity.

b. Added acidity .

c. Effect of superheating on acidity.

- In connection with this experiment the moisture content of the fats was determined approximately.

Method of Work

Determining the Smoking Temperature - The pans used for containers were small enamel pans with a diameter at the top of 3is inches. They we carefulły washed, rinsed, and dried over a low gas flame and, after being cooled, they were weighed to tenths of a gram upon the Falrbanks white pan balance. 
To each pan was added 100 grams of fat. Care was taken to avold getting any of the fat on the outside of the pan since this fat might smoke before the fat in the pan had become hot enough to smoke. To distribute the heat evenly to the bottom of the pan of fat a sand bath was used. The thermometer used for recording temperatures was a tested Centigrade thermometer graduated to tenths of a degree and recording a maximum temperature of $300^{\circ} \mathrm{C}$. To keep it uniformly exposen to the heated fat it was tied to a ring secured to a ring stand and allowed to hang down so that the bulb was just covered by the fat, but did not touch the bottom of the pan. The heat used was from an electric stove so there was not the uneven distribution obtained by a direct flame. In order to have a uniform background for observing the appearance of smoke the same electric plate was used in each case and the black surface of the warming shelf on the back of the stove served to give a uniform color which easily showed the fumes of smoke. The observations were made from approximateIy the same position each time. The temperature at which the first white fumes were seen to rise from the fat was considered the smoking temperature.

After the first observation of smoking temperature was made the pans of fat were cooled and weighed upon the Fairbanks balances to get an approximate idea of the amount 
of moisture which they contained. Then the fats were reheated to verify the previously recorded smoking temperaturea. This was repeated until experience gave a more nearly uniform judgement of the smoking temperature so that results did not vary more than two or three degrees.

The Relation of the Temperature at Which Smoking Begins and that at Which Smoking Ceases - In this experiment pans of fat were heated until fumes of smoke appeared. Then the heat was turned off. The heat in the sand and pan would cause the femperature of the fat to go on up ten or fifteen degrees higher and then it would gradually come down until smoking ceased. This temperature was recorded. The experiment was repeated two or three times.

The Effect of Changing the Size of the Pan - Samples of corn oil and of oleomargarine fat were used for this experiment. The oleomargarine was heated gradually until the casein settled to the bottom of the pan and browned slightly. Then the fat was poured off and one sample of it was put into a small granite pan and the other into an aluminum pan with a diameter of $7 \frac{1}{2}$ inches. In each case fat enough was used to cover the bulb of the thermometer. A sand bath large enough for the larger pan was improvised so that it would be heated under conditions similar to those of the smaller pan. The smoking temperature was observed in both pans and repeated until results agreed closely enough to warrant conclusions. The corn oil was heated in the same pans after they had been thoroughly washed and dried. 
The Aclitty of the Fats - Since earlier experiments have proved that there is a relation between the smoking temperature and the acidity of the fat, the acidity of the fats used is reported in connection with the smoking temperature. The acid number is the number of milligrams of potassium hydroxide required to neutralize the free fatty acids in one gram of an oil or fat.

\section{Reagents :}

1. Alcohol - 85\% alcohol was used in the first experiments and these were verified later with $95 \%$ alcohol. To 1000cc of the alcohol was added $5 \mathrm{cc}$ of phenolphthalein solution to indicate the point at which it was made alkaline.

2. $\mathrm{N} / 10 \mathrm{NaOH}$ - An approximately tenth normal sodium hydroxide was obtained and this was titrated against a known solution of $\mathrm{HCl}$. The factor for the $\mathrm{NaOH}$ was found to be 1.123 times $\mathrm{N} / 10$.

Mothod:

Small beakers were washed, rinsed with distilled water and dried to be used to contain the olls so they could be more easily transferred to the flasks. 250ce Erlenmeyer flasks were washed with cleaning solution, rinsed with distilled water three or four times and then dried in a warm oven for an hour. The flasks were cooled and each flask was weighed on the sensitive balance to tenths of a milligrar. Into each flask was transferred approximately 10 grams of fat and the exact weight determined.

A burette gracuated to tenths of a centimeter was 
was used to contain the $\mathrm{NaOH}$. It was washed with cleaning solution and rinsed so that it drained evenly. It was rinsed with the $\mathrm{NaOH}$ and then refilled with the reagent. Enough of the $\mathrm{NaOH}$ was run into the liter of alcohol to cause the phenolphthalein to show a slight pink color.

To each flask containing fat was added 50cc of the neutralized alcohol to dissolve the fat. The flask was put upon a water bath and heated until it just reached the boiling point. It was partly cooled and the $\mathrm{NaOH}$ was mun into the flask, while it was kept stirred by shaking. When after vigorous shaking the pink color of the phenolphthalein just remained the number of cc of $\mathrm{N} / 10 \mathrm{NaOH}$ required was recorded.

The acid determination of the fats was repeated to verify these results. However in the second experiment 95\% alcohol was available and it was used instead of the $85 \%$ used before.

Method for the Calculation of the Acid Number of the Fats: Each ec of $\mathrm{N} / 10 \mathrm{NaOH}$ is equivalent to $5.6108 \mathrm{mg}$ of $\mathrm{KOH}$. Typical Calculation:

1. Welght of flask and peanut oil

2. Weight of flask

3. Weight of oil

4. cc of $\mathrm{N} / 10 \mathrm{NaOH}$ used. a. Reading before titration

b. Reading after titration

c. No. of cc of $\mathrm{N} / 10 \mathrm{NaOH}$ used

\begin{tabular}{cc}
$I$ & $I I$ \\
48.3545 & 44.9025 \\
37.5005 & 34.0435 \\
\hline 10.8540 & 10.8590
\end{tabular}

15.75

$\frac{20.90}{5.15}$ 
5. Corrected by factor 1.123

$5.682 \mathrm{cc} \quad 5.682 \mathrm{cc}$

6. Divided by number of grams of oil taken gives No. of ce of $\mathrm{NaOH}$ required to neutralize $1 \mathrm{gr}$. of oll

$.523 c 0 \quad .523 c c$

7. Multiplied by 5.6108 gives the number of $\mathrm{mg}$. of $\mathrm{KOH}$ required to noutralize one gram of the fat $2.93 \quad 2.93$

The Effoct of Changing the Acidity - A solid fat (lard) and an oil (corn oil) were used in this experiment:

To separate the fatty acids for this experiment ten grams of fat were weighed into each of two 500cc Erlonmeyer flasks. A solution of 25 grams of potassium hydroxide in $500 \mathrm{c}$ of alcohol had been made on the previous day and allowed to stand. 100ce of the alcoholic potash were added to the samples of fat and they were heated on a water bath for one hour. The alcoholic potash was then neutralized with $\mathrm{N} / 2 \mathrm{HCl}$ and an excess of acid added. The fatty acid separated and came to the top. By repeatedly washing it with distilled water and drawing off the water the fatty acid was washed free of $\mathrm{HCl}$ and was ready to be used in the experiment. To samples of lard and of corn oil whose smoking temperatures had already been found a portion of the related fatty acid was added and the smoking temperature again found,

The Effect of High Temperature - A pan of lard was heated until it reached $300^{\circ} \mathrm{C}$ and then cooled and reheated until fumes of snoke appeared. This temperature was compared with the orlginal smoking temperature of the lard. 
TABLE I

Moisture Content and Smoking Temperature of Fats

$$
\begin{aligned}
& \text { :Wt. of Pan: } \\
& \vdots \text { and }: \text { Wt after: } \\
& : 100 \mathrm{gr} \text { fat:heating.: }
\end{aligned}
$$

Name of Fat.: (grams.) : (grams.):Loss \%:Smoking Temperature:Ave.

Cotton Seed : Salad 0il: Wesson 011 : Corn 0 il : Cottolene : Crisco

Lard

oleo

Butter

Olive 011, : No. 1.:

olive 0il, : No. 2.:

Scorched Lard :

Suet

Corn 011 and: Fatty Acid:

\begin{tabular}{|c|c|c|c|c|c|c|c|c|}
\hline & : & : & & & & & : & \\
\hline 237.50 & : 237.10 & : & $.4:$ & 225, & 223, & 217 , & 221: & 221 \\
\hline 236.75 & $: 236.60$ & $:$ & $.15^{\circ}$ & 219 & 219 , & 219 & $:$ & 219 \\
\hline & $:$ & : & : & 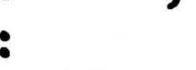 & & & : & \\
\hline 235.00 & $: 235.00$ & : & $.0:$ & : 215, & 215 & & : & 215 \\
\hline & : & $:$ & : & : & & & : & \\
\hline 233.00 & $: 233.00$ & : & $.0:$ & : 203, & 198, & 196, & 196: & 198 \\
\hline 232.40 & : 232.30 & : & $.1:$ & : 201, & 192, & 193, & 190: & 193 \\
\hline & : & : & : & : & & & $:$ & \\
\hline 238.40 & : 238.20 & : & .2 & : 193, & 191 & 190, & 192: & 191 \\
\hline 230.80 & : 218.40 & : & $12.4:$ & : 173, & 169 , & 169, & 167: & 170 \\
\hline 100 & : & : & $7:$ & : & & & $:$ & \\
\hline 199.40 & $\begin{array}{l}: 186.60 \\
:\end{array}$ & $:$ & $12.8:$ & : 175 , & 175, & 178 & $:$ & 176 \\
\hline & : & : & & : & & & : & \\
\hline 233.20 & : 232.80 & $:$ & .4 & 165, & 166 , & 165 & : & 165 \\
\hline & : & : & & : & & & : & \\
\hline 236.25 & : 236.20 & : & .05 & : 165 , & 164, & 163 & : & 164 \\
\hline & : & : & 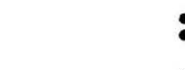 & : & & & : & \\
\hline & : & : & & : & & & : & \\
\hline & : & : & & : 176, & 176, & 172 & : & 175 \\
\hline & : & : & & : & & & : & \\
\hline & : & : & & : 166, & 164, & 166 & : & 165 \\
\hline & : & : & & : & & & : & \\
\hline & : & $:$ & & $:$ & & & $:$ & \\
\hline & : & : & & : 172, & 173, & 171 & : & 172 \\
\hline & : & : & & : & & & $:$ & \\
\hline & : & : & : & : & & & : & \\
\hline & $:$ & $:$ & $:$ & : 175, & 175 & & : & 175 \\
\hline
\end{tabular}

Lard and Fatty Ac1d: 
Wt of

Name of Fiagk

Fat and Fat

lene II 59.278549 .3605

C. S.

Salad I $59.2000 \quad 46.4400 \quad 12.7600$

OiI II $63.8140 \quad 53.5570 \quad 10.2570$

Iard I 52.2300 40.6300 11.6000 II 62.955551 .263511 .6920

0leo I $46.1865 \quad 35.5090 \quad 10.6775$ II $59.6315 \quad 49.6515 \quad 9.9800$

ButterI 56.0080 45.5050 10.5030 II $43.3415 \quad 35.4600 \quad 7.8815$

Corn I 56.7200 49.0900 7.6300

Oil II $63.9190 \quad 53.5570 \quad 10.4620$

PeanutI 48.3545 \%7.5005 10.8540 II $44.9025 \quad 34.0435 \quad 10.8590$

$I$.

I $61.2800 \quad 50.1100 \quad 11.1900$

OIiveII $64.7875 \quad 54.358510 .4350$

P. I 60.1400 48.5200 11.6200

OIiveII $64.617254 .1775 \quad 10.4397$

CriscoI

II 56.725546 .173010 .5525

WessonI 48.220033 .210015 .0100

Oil II 55.972545 .505510 .4675

suet I 64.435054 .351010 .0840 ScorenI II $56.2695 \quad 46.1720 \quad 10.0965$

ed I

Iard II
$5 \mathrm{cc}$

$5 \mathrm{cc}$
17.5518 .10

7.80 .7 .25

$4.5 \quad 5.6$

20.922 .05

24.0526 .10

0.852 .70

14.0515 .50

15.5016 .05

19.4019 .75

$24.00 \quad 24.45$

$15.75 \quad 20.90$

10.6015 .75

10.0513 .65

$3.4 \quad 6.8$

14.017 .2

$7.8 \quad 10.6$

3.253 .0

26.1026 .85

18.3519 .05

$6.80 \quad 7.25$

$16.65 \quad 20.30$

$20.30 \quad 24.10$

10.811 .7

$11.7 \quad 12.55$ cc of ed by N/10 ractor $\mathrm{NaOH} 1.123$

cc

.123

5.6108

Acid Num-

cc

$\mathrm{Ifg}$ of $\mathrm{KOH} \mathrm{lig}$ of $\overline{\mathrm{KOH}}$

0.65

0.72

0.42

$\begin{array}{lll}0.75 & 0.84 & 0.47\end{array}$

0.440

\section{$\begin{array}{lll}0.55 & 0.62 & 0.269\end{array}$}

$0.45 \quad 0.605 \quad 0.269$

$\begin{array}{lll}1.1 & 1.23 & 0.597\end{array}$

$1.15 \quad 1.29^{\prime} \quad 0.610$

$2.05 \quad 2.30 \quad 1.20$

1.95

1.45

1.15

0.35

0.45

5.15

5.15

3.60

3.4

3.2

2.8

0.75

0.75

0.70

0.45

2.19

1.20

1.628

1.12

1.29

0.91

0.393

0.505

5.68

5.68

4.03

3.818

3.59

0.29

0.27

2.93

2.93

2.02

2.05

1.73

3.14

1.68

0.47

0.84

0.45

0.786

0.29

0.505

0.27

3.65

4.098

2.24

3.70

4.155

2.30

0.269

0.603

1.16

0.88

0.28

2.93

2.035

1.705

0.460

0.28

0.90

1.01

0.85

0.95

1.19

1.07

1.13 
TABLE III

Comparison of the Smoking Temperature and Acidity.

Smoking Temperature $\mathrm{Mg}$. of $\mathrm{KOH}$ per Degrees Centigrade. $\quad 1 \mathrm{gr}$. of fat

Salad Oil

221

.27

Wesson

219

215

198

193

192

176

175

170

165

165

Olive 011

Oleo

Olive 0 il

Suet
164
2.03

Corn

.28

.28

.44

.46

.60

.88

1.13

1.16

1.70

2.27

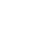




\section{TABLE IV}

The Effect of Difference in Size of the Pan

$$
\text { Diameter of Pan }
$$

$$
\begin{array}{cc}
\text { I. } 3 \frac{1}{2} \text { inches } & \text { II. } 7 \frac{1}{2} \text { inches } \\
\text { Smoking Temperature } \\
\text { (degrees Centigrade) } \quad \text { (degrees Centigrade) }
\end{array}
$$

$\begin{array}{lll}\text { Oleo (1) } & 169 & 161 \\ \text { (2) } & 169 & 164 \\ \text { (3) } & 167 & 165 \\ \text { Ave. } & 168 & 167\end{array}$

Corn 0 il

(1) $206 \quad 206$

$\begin{array}{ll}\frac{206}{206} & \frac{207}{206.5}\end{array}$

Corn $011 \quad$ (1) 194 192

(containing

fatty acid) (2) $192 \quad 190$

$193 \quad 191$ 
Discussion of Results

Smoking Temperature and Acidity - In general these results agree ith the statement made by Blunt and Feeney that the greater the acidity of a fat the lower its smoking temperature. The wesson oil with an acidity of .28 smokes at $219^{\circ} \mathrm{C}$ while the 0live oil with an acidity of 2.03 smoked when it reached $165^{\circ} \mathrm{C}$. The addition of fatty acid to the corn oil changed 1 ts smoking temperature from $215^{\circ}$ to $172^{\circ}$ and the lard upon the addition of fatty acid dropped from $1.91^{\circ}$ to $175^{\circ}$. Heating lard to $300^{\circ} \mathrm{C}$ caused its smoking temperature to drop from $191^{\circ}$ to $175^{\circ}$. The fats which would heat to the frying temperature $185^{\circ}$ to $195^{\circ}$ without smoking were the cottonseed olls and their products, and corn oil. The statement is sometimes made by cooks that if a fat is heated until it smokes, it will be at the right temperature for frying. This might be true of lard since it began to smoke at $191^{\circ}$. However, if Wesson oil or corn oil were heated until they smoked before they were used for frying, the food would be cooked at a temperature of from $215^{\circ}$ to $225^{\circ} \mathrm{C}$ instead of at $185^{\circ}$ to $190^{\circ}$ as is customary. When lard was heated as far as $185^{\circ} \mathrm{C}$ it became somewhat dark and when it became cool it had a grayish color. This is probably due to finely divided tissue in the fat. On heatin oleomargarine and butter the easein changes color at $185^{\circ}$ and settles to the bottom. If the fat is heated to a higher temperature this casein be- 
comes burned and makes these fats undesirable for deep frying. The fat can be poured off of the casein and used but it gives off smoke before it reaches $185^{\circ} \mathrm{C}$.

The olls and fats, other than butter, oleo, and lard, did not change color during the temperature tests. However, it was observed later in work done with wesson oil and with corn oil that when they were used ropeatedly for frying doughnuts, they became darker in color.

The change in the size of the pan did not make as great a difference in the smoking temperature as was recorded by other observers. It was noted, however, that the smoke was easier to see when the bulk of the fat was greater. The difference for the fats was: 0leo, $168^{\circ}$ to $167^{\circ}$; corn oil, $206^{\circ}$ to $206.5^{\circ}$; another sample of corn $011,193^{\circ}$ to $191^{\circ}$. It seems quite probable that the $f$ at in a large pan would be more unevenly heated and one part of the pan might be several degrees hotter than another part. Two thermometers recording approximately alike were suspended over the large pan of fat--one at the center of the fat, the other at the edge--and there was a difference of one degree in the temperature they recorded, even though a sand bath was used under the pan.

When the experiment was begun, it was observed that often when a fat was heated until the smoking temperature was found and the fat was removed from the stove it would continue to smoke for sometime, often smoking more profusely 
after the removal than before. By continuing to observe the fat after it had been taken from the fire, it was found that the temperature would continue to rise from $10^{\circ}$ to $15^{\circ}$, due to the heat conducted to it from the pan. Blunt and Feeney made the observation that"fats after heating to their smoking temperatures often continued to smoke after the flame had been taken away. It was noticed in a number of cases that the fumes were given off until the mercury had fallen 200 below the smoking temperature.

It was with the intention of verifying this latter statement that the temperature at which the fats stopped smoking was observed. After repeated observations, it was concluded that, if the first smoke was carefully observed when the fat was heating, it would stop smoking within one or two degrees of the temperature at wich it began. For instance, oleomargarine began smoking at $169^{\circ}$, the temperature of the fat went on up several degrees after the pan was removed from the fire and, as the pan cooled, it continued to smoke until the thermometer recorded $167^{\circ}$. Cottolene, which began smoking at $198^{\circ}$, showed, on cooling, no signs of smoke below $196^{\circ}$.

It is probable that if a fat were heated very far above its smoking temperature it would continue to smoke after it cooled below the first smoking temperature recorded, because of a change made in its composition by the high temperature. Heating lard to $300^{\circ} \mathrm{C}$. caused its smoking temperature to drop $16^{\circ}$. Therefore, this pan of lard which just smoked 
at $191^{\circ}$, when heated on up to $300^{\circ} \mathrm{C}$ would, on cooling, continue to smoke unt1l it dropped to its new smoking temperature of $175^{\circ}$.

After heating fats to a few degrees above the smoking temperature and then cooling and reheating, no decided change in smoking temperature was shown. No appreciable change in acidity occurred. This latter conclusion was drawn from some preliminary tests which were made upon the acidity of the fats.

$5 \mathrm{cc}$ of fat were measured in a pipitte and transferred to 250 cc flasks. $50 \mathrm{cc}$ of neutralized alcohol was added and $\frac{1}{2}$ cc of phenolphthalein. The contents of the flask was heated on the water bath and the No. of $\mathrm{cc}$ of $\mathrm{N} / 10 \mathrm{NaOH}$ required to neutralize the fatty acid was noted. Two samples of fresh fat or oil and two samples of heated fat were used. Some of the figures follow:

$$
\begin{array}{r}
\text { cc of } N / 10 \mathrm{NaOH} \text { required to } \\
\text { neutralize } 5 \text { cc of oil or fat. }
\end{array}
$$

\begin{tabular}{|c|c|c|}
\hline Peanut 0 il & fresh & $\begin{array}{l}a \\
b\end{array}$ \\
\hline & after heating & $\begin{array}{l}a \\
b\end{array}$ \\
\hline Corn Oil & fresh & $\begin{array}{l}a \\
b\end{array}$ \\
\hline & after heating & $\begin{array}{l}a \\
b\end{array}$ \\
\hline 0100 & fresh & $\begin{array}{l}a \\
b\end{array}$ \\
\hline & after heating & $\begin{array}{l}a \\
b\end{array}$ \\
\hline
\end{tabular}




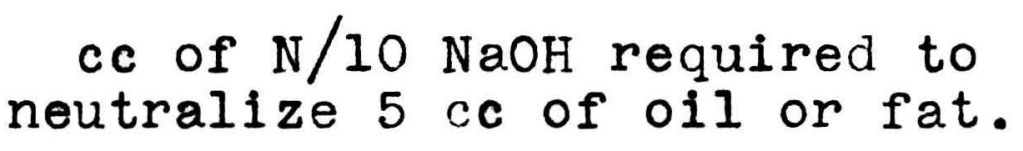

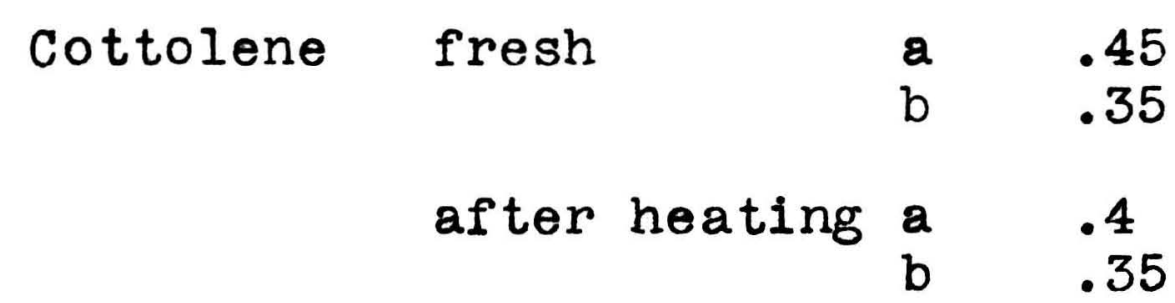

$>$ Moisture Content - The proportion of moisture in all of the fats tested except the butter and oleomargarine was practically negligible. Therefore, we may conclude that most of the fats on the market are "all pure fat", a statement used to a great extent by various firms advertising their fats. Such statements as the following show the extent to which this is carried:
"If you use 'Simon Pure', be sure to use one quarter less than of any other shortening for, being all pure shortening, it goes further than any other". 41 "In shortening, you use from $1 / 3$ to $1 / 4$ less Mozola than you are obliged to use with ordinary shortening. Being highly refined, Mozola goes a long way." 42 "Wh1te cliff --shortening; use $1 / 3$ less than lard." 43 "Because of its purity and superior quality, Simon Pure goes a third farther than ordinary lard." 44

41

Adams. Personal letter from Armour and Companv - Chieago 1916.

42

Mozola Cook Book - Corn Broducts Refining Co,-New York. 43

Printed on the can. 
The only important difference in water content of the fats is in the oleomargarine and butter, each of these containing more than $12 \%$ of water. In the ease of the other fats, it may be said that cottolene compaund, the oils, crisco, lard, etc. are all practically 100\% fat. Summary (Smoking Temperature and Acidity, and Moisture Content)

1. There is an inverse relation between the smoking temperature and the acidity of fats.

2. Heating a fat $100^{\circ}$ above its original temperature lowers its snoking temperature and increases its acidity .

3. The temperature at which a fat stops smoking is approximately. the same as that at which it began provided the fat was not heated long after it began to smoke.

4. A change in the size of the pan from one having a diameter of $3 \frac{1}{2}$ inches to one having a diameter of $7 \frac{1}{2}$ inches did not change the smoking temperature appreciably.

5. Heating the fats to test their smoking temperatures made no change in their color or appearance except in the case of lard, oleo, and butter. The lard became dark, and the other two fats lost moisture and the casein became burned. 
6. Heating these fats to test their smoking temperatures from $190^{\circ}$ to $220^{\circ} \mathrm{C}$ did not change their acidity appreciably.

7. With the exception of butter and oleomargarine, the moisture content of all the fats tested was negligible. Hence, they are all practically 100\% shortening.

The Absorption of Fat in Frying

Purpose of Experiment

To determine:

1. The quantity of fat absorbed when different temperatures are used for frying.

2. The extent to which animal and vegetable fats are absorbed when the same temperatures are used.

3. The quantity of fat absorbed when different methods of mixing and different shapes of doughnuts are used.

4. The percent of moisture lost in frying at different temperatures.

Method of Work

The fats used for frying were lard, crisco, corn o1l, and wesson oil.

The food used for frying was doughnuts made from proportions taken from the following reclpe: 4 cups flour, 4 teaspoons baking powder, $1 \frac{2}{2}$ cups sugar, 2 eggs, 3 table- 
spoons fat, $7 / 8$ cup water, salt and seasonings. The quantities which were mixed at one time were:

$$
\begin{array}{cl}
\text { Mixture I - } & \text { Flour } 900 \mathrm{gr} \cdot / 155 \mathrm{gr}=1055 \mathrm{gr} . \\
& \text { Sugar } 454 \mathrm{gr} . \\
& \text { Eggs } 4 \mathrm{Hg} . \\
& \text { Oleo } 60 \mathrm{gr} . \\
& \text { Water } 1 \frac{3}{4} \text { cups } \\
& \text { Salt } 1 \mathrm{~T} \\
& \text { B. P. } 2 \mathrm{~T} .
\end{array}
$$

Method of mixing I - The flour, sugar, salt, and baking powder were mixed in a large bowl. The eggs, water, and melted oleo were beaten together, and then added to the dry materials and the whole mixed until it formed a stiff dough.

The board for rolling the dough had strips of wood put on each side close enough together to allow the rolling pin to run on the strips of wood. This gave the dough a uniform thickness. The doughnuts were cut with a doughnut cutter which made them very near the same size.

To measure the flour which had to be used in rolling, a pan containing flour was weighed and the flour for rolling used out of this pan. The pan and the flour not used were weighed afterwards and the difference gave the quantity of flour used for rolling. This amounted to $155 \mathrm{gr}$. of flour.

As the doughnuts were cut they were laid upon trays covered with floured paper to avoid sticking. The doughnuts were covered with linen towels to retard drying out until the whole number were finished. 
The doughnuts were weighed in groups of four, and one group taken for each experiment.

The fats for frying were put into the bottom parts of enamel double boilers. About $500 \mathrm{gr}$. of fat were used in each experiment. The pans and fats were heated until they reached $185^{\circ} \mathrm{C}$ and were weighed while hot upon the balances. They were weighed hot because the fat was to be weighed after each group of doughnuts were fried to get the quantity of fat lost by absorption. Since it was thought too inconvenient to wait for the pan of fat to cool each time it was weighed, the weights were all taken at about $185^{\circ} \mathrm{C}$.

The stove used was an electric stove. The thermometer for getting the temperature of the frying fat was suspended from a ring fastened to a ringstand so that the bulb was always covered by the fat but was not allowed to reach the bottom of the pan. The order of frying ran as follows:

The doughnuts of known weight were fried at a definite temperature for a definite length of time in a pan of fat which had been weighed. The fried doughnuts were taken out upon a fork and drained over the fat for one-ha]f minute and then put into a pan and weighed. The pan of fat was Peighed to get the grams of $f$ at absorbed.

Method II - Since the first experiment was not extensive enough to warrant convincing conclusions, another mixture of dough was made and fried. Some difference was made in the later experiment. The proportions used were: 


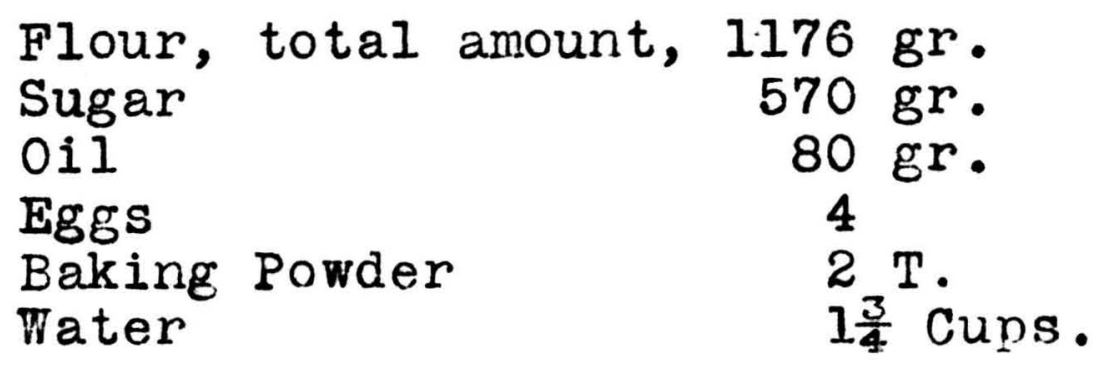

Oil was used instead of oleo since the oleo was inclined to harden in the liquid. 80 grams of oil was used so the doughnuts would be more tender. More sugar was used to make them more palatable. The dough wes mixed by having the sugar added to the liquids so it would be more evenly dissolved. In the first dough, little specks of partly dissolved sugar could be seen thraughout the dough. It was thought probable that the shape of the doughnuts had some influence upon the fat absorbed so this second mixture of dough was cut in small biscuit shapes except for a few which were cut with the doughnut cutter to compare w1th the first work. The method of weighing the doughnuts and the fat was the same as was used wi th the first group. 
TABIE V

Doughnuts Ifixed by Hethod 1 and Cut in Shape of Doughnuts.

\begin{tabular}{|c|c|c|c|c|c|c|c|}
\hline $\begin{array}{l}\text { Kind of rat } \\
\text { Used for } \\
\text { Frying }\end{array}$ & $\begin{array}{l}\text { Wt of Raw } \\
\text { Doughnuts } \\
\text { (grams) }\end{array}$ & $\begin{array}{l}\text { Wt of Fat } \\
\text { Before Fry- } \\
\text { ing (grams) }\end{array}$ & $\begin{array}{l}\text { Wt of Fat } \\
\text { After Frying } \\
\text { (grams) }\end{array}$ & $\begin{array}{l}\text { Fat } \\
\text { Absorbed } \\
\text { (grams) }\end{array}$ & $T_{C}$ & $\begin{array}{l}\text { Tine } \\
\text { Iin. }\end{array}$ & $\begin{array}{l}\text { Fat Absorbed } \\
\text { per loo gr. } \\
\text { of Doughnuts } \\
\text { (grams) }\end{array}$ \\
\hline $\begin{array}{cc}\text { Wesson } & \text { Oil } \\
" & " \\
" & " \\
\end{array}$ & $\begin{array}{l}131.0 \\
133.0 \\
132.5 \\
\end{array}$ & $\begin{array}{l}1034.5 \\
1019 \cdot 5 \\
1006.2 \\
\end{array}$ & $\begin{array}{r}1019.5 \\
1006.2 \\
993.0 \\
\end{array}$ & $\begin{array}{l}15.0 \\
13.3 \\
13.2 \\
\end{array}$ & $\begin{array}{l}175 \\
185 \\
195 \\
\end{array}$ & $\begin{array}{l}7 \\
4 \\
4 \\
\end{array}$ & $\begin{array}{r}11.4 \\
10.0 \\
9.9 \\
\end{array}$ \\
\hline $\begin{array}{cc}\text { Corn } & \text { Oil } \\
" & "\end{array}$ & $\begin{array}{l}132.0 \\
135.0 \\
131.6 \\
\end{array}$ & $\begin{array}{r}1012.0 \\
997.0 \\
983.0 \\
\end{array}$ & $\begin{array}{l}997.0 \\
983.0 \\
973.0 \\
\end{array}$ & $\begin{array}{l}15.0 \\
14.0 \\
10.0\end{array}$ & $\begin{array}{l}175 \\
185 \\
195 \\
\end{array}$ & $\begin{array}{l}5 \\
4 \\
3.5 \\
\end{array}$ & $\begin{array}{r}11.3 \\
10.5 \\
7.6 \\
\end{array}$ \\
\hline $\begin{array}{c}\operatorname{Lard} \\
" \\
\end{array}$ & $\begin{array}{l}134.0 \\
132.0 \\
130.5\end{array}$ & $\begin{array}{l}932.0 \\
918.0 \\
905.5 \\
\end{array}$ & $\begin{array}{l}918.0 \\
905.5 \\
894.0 \\
\end{array}$ & $\begin{array}{l}14.0 \\
12.5 \\
10.5 \\
\end{array}$ & $\begin{array}{l}175 \\
185 \\
195 \\
\end{array}$ & $\begin{array}{l}5 \\
4 \\
3 \\
\end{array}$ & $\begin{array}{r}10.4 \\
9.4 \\
8.0 \\
\end{array}$ \\
\hline $\begin{array}{c}\text { Crisco } \\
" 1\end{array}$ & $\begin{array}{l}133.7 \\
131.7 \\
132.3 \\
\end{array}$ & $\begin{array}{l}913.0 \\
901.0 \\
890.0 \\
\end{array}$ & $\begin{array}{l}901.0 \\
890.0 \\
880.0 \\
\end{array}$ & $\begin{array}{l}12.0 \mathrm{n} \\
11.0 \\
10.0 \\
\end{array}$ & $\begin{array}{l}175 \\
185 \\
195 \\
\end{array}$ & $\begin{array}{l}5 \\
4 \\
3 \\
\end{array}$ & $\begin{array}{l}9.0 \\
8.3 \\
7.5 \\
\end{array}$ \\
\hline $\begin{array}{l}\text { Wesson Oil } \\
\text { (Dougrnuts } \\
\text { from second } \\
\text { mixture) }\end{array}$ & $\begin{array}{l}133.5 \\
138.5 \\
140.0 \\
\end{array}$ & $\begin{array}{l}1147.0 \\
1131.0 \\
1112.3\end{array}$ & $\begin{array}{l}1131.0 \\
1112.5 \\
1093.5\end{array}$ & $\begin{array}{l}16.0 \\
18.7 \\
18.8 \\
\end{array}$ & $\begin{array}{l}194 \\
196 \\
196 \\
\end{array}$ & $\begin{array}{l}3 \\
3.5 \\
3\end{array}$ & $\begin{array}{l}11.4 \\
12.7 \\
13.4 \\
\end{array}$ \\
\hline
\end{tabular}




\section{TABIE VI}

Doughnuts Mixed by Method 2 and Cut in Shape of Small Biscuits

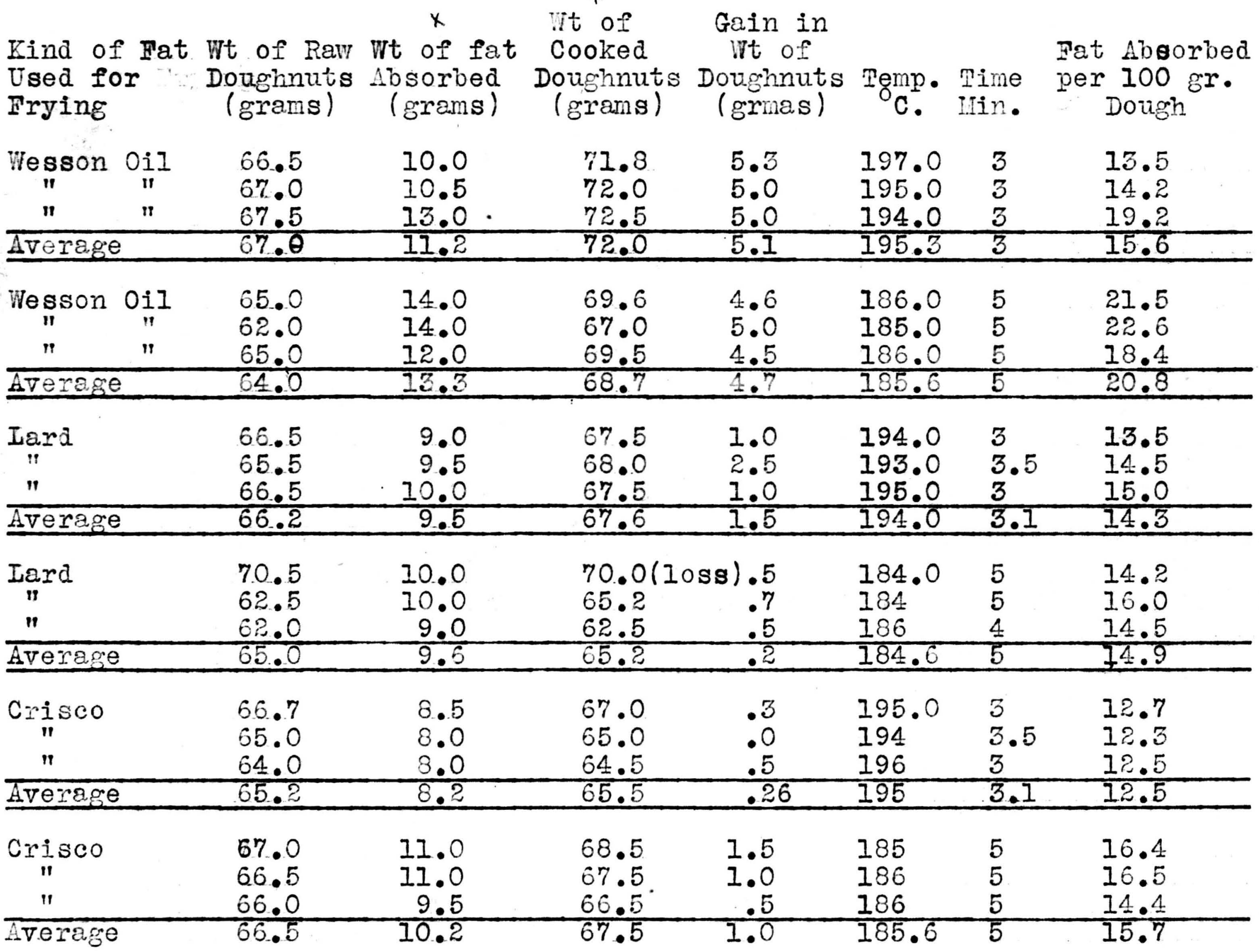


Discussion of Results

1. Throughout both experiments it was found that, other conditions being equal, the lower the frying temperature used, the greater the quantity of fat absorbed.

2. The oils were absorbed to a grdater extent than the solid fats when the temperatures were the same. Compare:

Doughnuts From Name of Mixture Number Frying Fat

$\begin{array}{rlrrr}\text { I } & \text { Wesson 0il } & 11.4 & 10.0 & 9.9 \\ \text { I } & \text { Corn 0il } & 11.3 & 10.5 & 7.6 \\ \text { I } & \text { Lard } & 10.4 & 9.4 & 8.0 \\ \text { I } & \text { Crisco } & 9.0 & 8.3 & 7.5 \\ \text { II } & \text { Wesson 0il } & & & 12.6\end{array}$

(Shaped like biscuits.)

II

Wesson 0 il

Lard

Crisco
Grams of Fat Absorbed

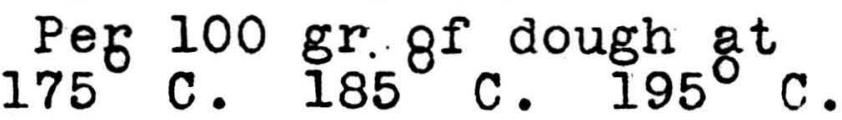

$11.4 \quad 10.0 \quad 9.9$

$\begin{array}{lll}11.3 & 10.5 & 7.6\end{array}$

10.4
II

II

20.8

16.6

$14.9 \quad 14.3$

15.7

12.5

Crisco

3. The resson oil absorbed by the mixture number II at the same temperature $195^{\circ}$, but by different shaped doughnuts was for the regular doughnuts $12.6 \%$ for the small round shapes, $15.6 \%$

4. The second mixture, containing more fat and sugar produced doughnuts which were more tender than those from the first mixture. 
5. The fat absorbed by the different mixtures I and II, same shaped doughnuts, same frying fat (wesson oil), same temperature $\left(195^{\circ}\right)$ was for mixture I, $9.9 \%$; for mixture II, $12.6 \%$. Therefore, the greater quantity of fat and sugar put into the dough, caused a higher proportion of fat to be absorbed in frying.

6. The solid vegetable fat, (crisco) was not absorbed to a greater extent, other onditions being eanal, than the solid animal fat, lard. In fact, on the average, it was not absorbed in as great quantity as the lard. Compare:

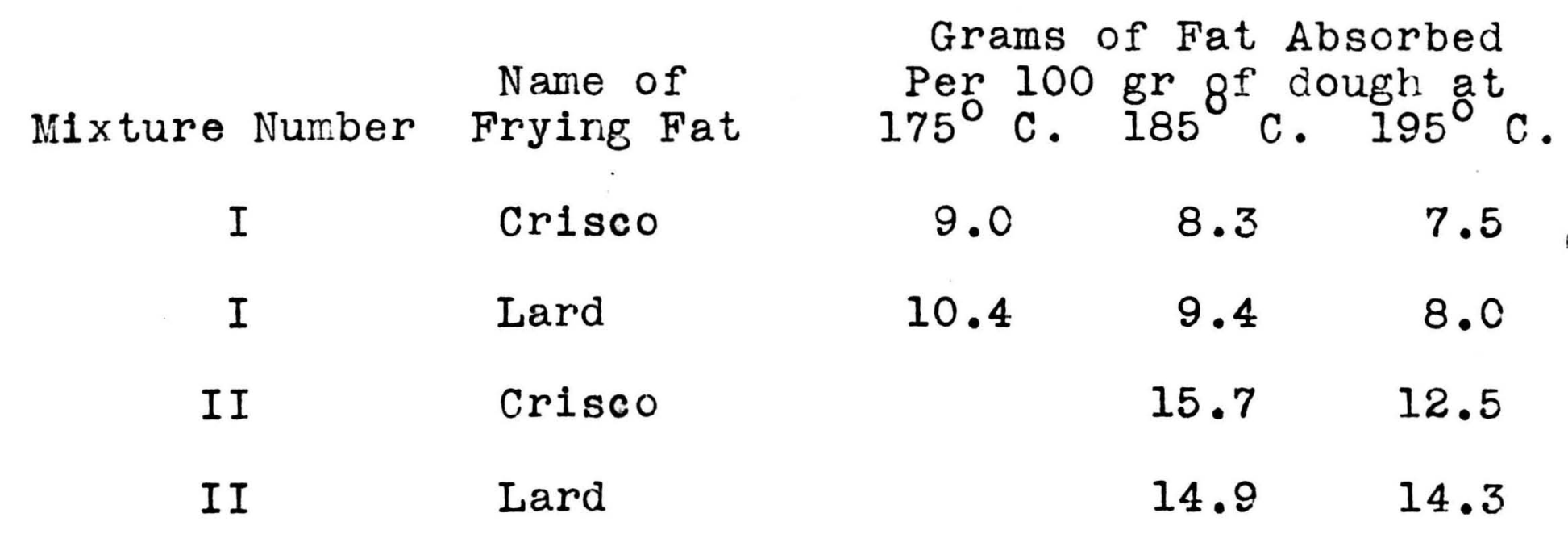

Therefore, the general statement cannot be made that vegetable fats are absorbed to a greater extent than the animal fats at the same temperature. It seems to be more nearly true that oils are absorbed to a greater extent than solid fats, regardiess of their animal or vegetable source.

7. Assuming that the difference between the weight of the raw dough and the cooked dough from which has been sub- 
tracted the weight of fat absorbed will give the auantity of moisture lost in cooking at different temperatures, wo find from table VI:

Cooked

Doughnuts

Wt. of Raw Less Fat Moisture Moisture

$\begin{array}{lccc}\text { Name of Doughnuts Absorbed } & \text { Lost } & \text { Lost Temp. } \\ \text { Frying Fat grams } & \text { grams } & \text { gramst. Percent. } & { }_{C} \text {. }\end{array}$

$\begin{array}{llllll}\text { Wesson } 011 & 67 . & 60.8 & 6.2 & 9.2 & 195\end{array}$

$\begin{array}{llllll}\text { Lard } & 66.2 & 58.1 & 8.1 & 12.2 & 194\end{array}$

\begin{tabular}{llllll} 
Crisoo & 65.2 & 57.3 & 7.9 & 12.1 & 195 \\
\hline
\end{tabular}

$\begin{array}{llllll}\text { Average } & 66.1 & 58.5 & 7.6 & 11.5 & 194.6\end{array}$

\begin{tabular}{|c|c|}
\hline Wesson Oil & 64 \\
\hline
\end{tabular}

\begin{tabular}{|c|c|}
\hline Lard & 65. \\
\hline
\end{tabular}

\begin{tabular}{llllll} 
Crisco & 66.5 & 57.3 & 9.2 & 13.8 & 185.6 \\
\hline Average & 65.2 & 56.1 & 9.1 & 13.9 & 185.3
\end{tabular}

From this table we may conclude that a higher temperature of cooking causes less moisture to be lost and hence produces a doughnut which is not so dry. A comparison of the cooked doughnuts did not show that those cooked at $195^{\circ} \mathrm{C}$ were undercooked. Granting that those cooked at $195^{\circ} \mathrm{C}$ for three minutes are not undercooked, we should conclude that the higher temperature produces a more desirable doughnut becouse it is more molst and has absorbed less fat. Therefore, we would choose for frying a fat which will not smoke if heated to $195^{\circ} \mathrm{C}$. There was not an objectionable amount of smoke from any of the fats used except the lard. 
9. The lard was used satisfactorily at $185^{\circ} \mathrm{C}$ except that the doughnuts were less moist. The fat absorbed at $185^{\circ} \mathrm{C}$ was less $(14.9 \%)$ than was absorbed by wesson oil at $195^{\circ} \mathrm{C}(15.6 \%)$.

10. The crisco could be heated to $195^{\circ}$ satisfactori1y. At that temperature the doughnuts were moist and did not absorb as much fat as they did when fried with any other fat or oil used at that temperature. Compare wesson oil $15.6 \%$, lard $14.3 \%$, crisco $12.5 \%$ of fat absorbed at $195^{\circ}$.

11. Referring back to table VI, we find the cooked doughnuts to contain absorbed fat to the extent of:

Wesson oil \% of Fat Absorbed Per Wt. of Cooked Doughnuts at - $195^{\circ} \mathrm{C}$

Lard 21.6 30 .

Crisco 21.1 22.8 19. 23.

Therefore, the cooked doughnuts contained from $19 \%$ to $30 \%$ of absorbed, fat, the quantity depending upon the temperature and the kind of fat used for frying.

12. An observation of the fats after they had been used for frying the doughnuts showed that in every case they had become somewhat darker. The greatest change was shown by the lard which darkened at the first heating. Iittle change was shown in the other fats until they had been used for some time. The crisco which 
The Use of Fats in Pastry.

Changes in the Composition of Fat

Purpose of Experiment

To determine:

1. The changes occurring in the fat cooked in pastry.

2. The difference in the quantity of fat which may be extracted from cooked pastry and that which may be extracted from the dough which has not been cooked.

3. The effect of varlous cooking fats unon the

- mixing of the dough, the texture, specific volume, and flevor of pastry.

4. The influence of different proportions of oll and water upon the texture and specific volume of pastry.

5. The effect of baking powder upon the lightness and texture of pastry containing oil.

Methods of Work

I. The Changes Oecurring in Fat Cooked in Pastry Making the pastry. The weight of a cup of flour was determined and the fat and water were weighed upon the Falrbanks pan balance. 
was heated for two and a half hours was a little yellow in color and, on cooling, separated into a yellow oil and white solid fat.

The corn oil which was heated for one and a half hours had changed to a darker shade of yellow.

The wesson oil, heated for three hours, had changed to a light brown color. Its acidity had increased from $.28 \mathrm{mg}$ to .58 .

13. The flavor of the frying fats was observed by having people to taste the doughnuts without knowing the fat in which they were fried. The doughnuts were flavored also with the regular spices, cinnamon and nutmeg. A tabulated record of the results was not made for no one claimed to recognize any difference in flavor due to the frying fat used. These observations, however, were not very carefully made. 
The fat used (oleomargarine) was cut into the flour wi th a spatula, until the flour and fat looked evenly mixed. Then the cold water was added and the dough pushed together with the spatula until it would hold together. It was rolled out upon a board slightly floured and then put into a weighed tin. The raw dough was weighed.

It was baked in an oven recording from $220^{\circ}$ to $245^{\circ} \mathrm{C}$ for fourteen minutes. The crust and pan were cooled and weighed again. The crust was quite thoroughly baked and had a small bit of burnt edge. This was not removed since the total crust was thought to be about a typical one.

Since there is some fat in flour, the raw fat which was to be compared with the fat in the cooked pastry was not taken alone as raw fat, but was mixed with flour in the same proportions as those used in the pastry. However, water was not added. Then this fat was extracted in the same way as the cooked fat.

Extracting the fat. The pie crust was pulverized with a mortar and pestle. Large glass cones were prepared by putting cotton in the bottom and then filling them with samples of the pulverized crust and putting cotton in the top to keep the crust from coming out. The raw flour and fat was mixed with glass beads to keep it from packing so tight that the ether could not 
get through, and the cones were extracted in a Soxlet apparatus for ten hours with ordinary ether. Then the fat and ether which collected in the flasks were filtered to remove bits of flour or crust, and the ether evaporated. Oleomargarine alone was prepared to run with this experiment. The fat was melted and the casein allowed to settle. The fat was poured off, filtered, and gently warmed to drive off the remaining water.

The Iodine Absorption number of the three samples was determined by a slight modification of the method used by the Association of Official Agricultural Chemists.

Typical Calculation of Results.

Weight of fat taken cc of Wijs solution Thiosulfate equivalent to lodine

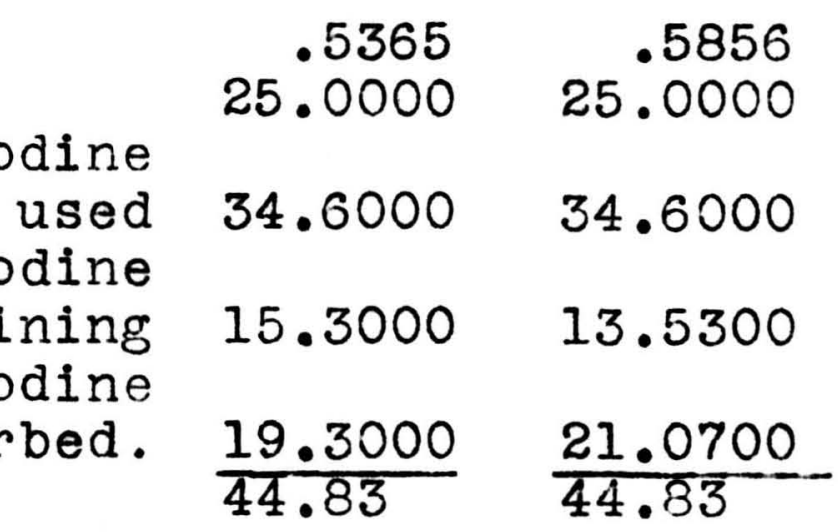
Thiosulfate equivalent to lodine

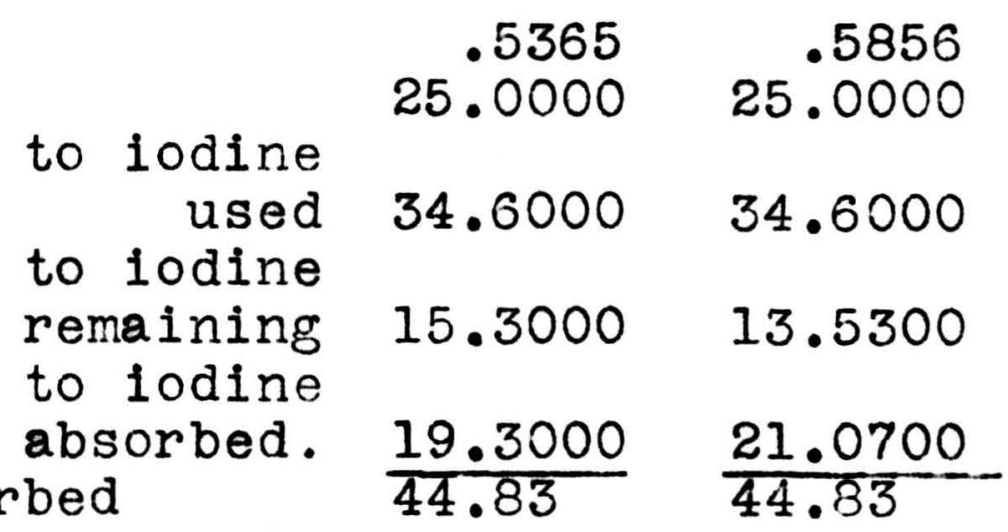
Thiosulfate equivalent to lodine Percent of lodine absorbed $\frac{19.30 \text { times } .01246 \text { times } 100}{\text { Wt. of sample } 0.5364}=44.83$

0.01246 is the iodine equivalent of each of the thiosulfate used. 
TABIE VII

Ioảine llumber

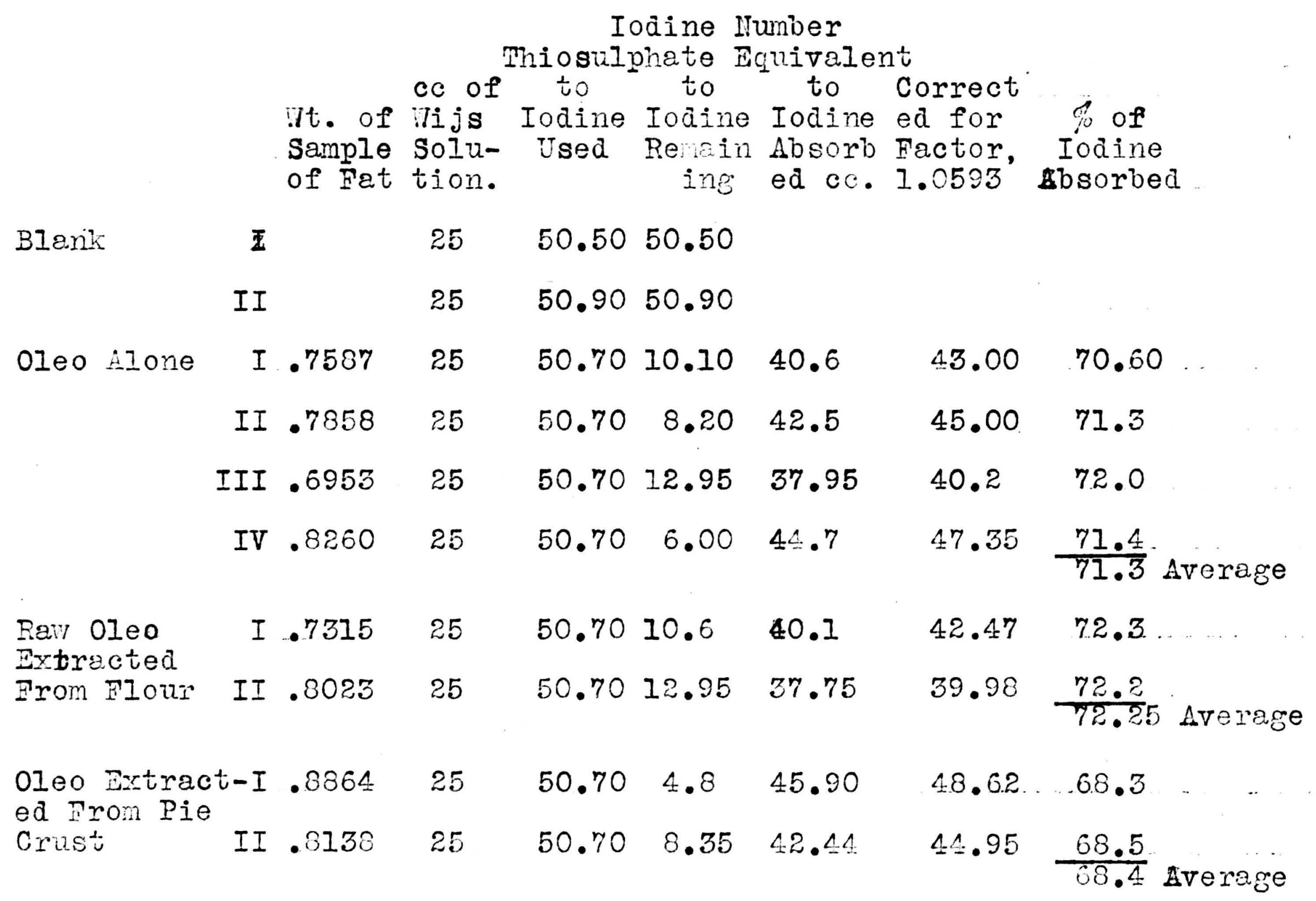


Iodine Number - The difference in iodine number found in the raw fat alone and that mixed with flour show that the flour changed the lodine number from 71.3 to 72.25. The cooked fat showed an iodine absorption number of 68.4. This indicated that a little change had been made in the oleomargarine which was cooked in this pastry.

The Saponification Number - The saponification number indicates the number of milligrams of potassium hydroxide required for the complete saponification of one gram of an oil, fat, or wax. The method used for the determination was that used by the Association of official Agricultural Chemists.

In the experiment three samples of fat were taken from each of (1) the raw oleomargarine, (2) the oleomargarine extracted from the fat and flour mixture, and (3) the oleomargarine extracted from the cooked pastry and tẉo blanks were run.

The raw oleomargarine was warmed until the casein and water settled and then the fat was poured off and gently warmed to drive off the remaining water, after which it was filtered to remove bits of casein.

Because of irregularities in results, due to cracked flasks, etc., only two of each group of the samples taken are given in the table. 


\section{TABLE VIII}

Saponification Number

\begin{tabular}{|c|c|c|c|c|}
\hline Wt. of & cc & $\begin{array}{l}\text { cc } \mathrm{N} / 2 \mathrm{HCl} \\
\text { Equivalent }\end{array}$ & & $\begin{array}{l}\text { Equivalent } \\
\text { in } \mathrm{Mg} \mathrm{KOH} \\
\text { Required to }\end{array}$ \\
\hline $\begin{array}{l}\text { Sample } \mathrm{KOH} \\
\text { grams. cc. }\end{array}$ & $\begin{array}{l}\mathrm{N} / 2 \mathrm{HCl} \\
\text { Used }\end{array}$ & $\begin{array}{l}\text { to Alkali } \\
\text { Combined }\end{array}$ & $\begin{array}{l}\text { Factor, } \\
1.1359\end{array}$ & $\begin{array}{l}\text { Saponify } \\
1 \text { gr of fat }\end{array}$ \\
\hline
\end{tabular}

Blank

$25 c c 24.79$

25cc $\frac{25.18}{24.98}$ Average

Oleo

\begin{tabular}{|c|c|c|c|c|}
\hline I 2.0744 & $25 \mathrm{cc}$ & 10.96 & 14.02 & 15.92 \\
\hline 2.0403 & $25 c c$ & 11.26 & 13.72 & 15.58 \\
\hline
\end{tabular}

Oleo From

Raw Fat

and Flour

Mixture

I $2.1306 \quad 25 c c \quad 9.86$

$15.12 \quad 17.17$

226

II $2.141125 \mathrm{cc} 10.14$

$14.84 \quad 16.85$

225

Cooked

Fat

$\begin{array}{rrrrrr}\text { I } 2.2690 & 25 \mathrm{cc} & 9.36 & 15.62 & 17.74 & 215 \\ \text { II } 2.1380 & 25 \mathrm{cc} & 10.34 & 14.54 & 16.62 & 218\end{array}$


The saponification number of the raw oleo was 214.5. When this fat had been mixed with raw flour, the saponification number was raised to 225.5 while that of the cooked fat was 216.3. Cooking has lowered the saponification number of the fat.

\section{The Extraction of Fat From Cooked Pastry}

Purpose of Experiment

The statement is made by Weibul1 $1^{45}$ that in attempting to extract fat from bread he found that it contained less fat than the flour from which it was made. He attributes this to the starch and dextrin of the bread which encloses the fat and prevents the action of the ether. It was thought desirable to find if fat was as thoroughly extracted from cooked as from raw pastry. The determination of the constants of cooked fat in pastry might contain an error if some of the fat were not extracted. Hence, this experiment was made in connection with the work on the fats cooked in pastry.

Method of Work

Samples of the piecrust and the raw flour and fat prepared above were used for this experiment. Six paper cones, each one stoppered lightly with cotton, were dried to constant weight. Then three of them were filled with samples of the pie crust and three with the raw mixture. 45

Weibull, M. "Fat in Bread" Svenskkemusk Tidskrift 1892 No. 5. Abstract in Experiment Station Record Vol. V, p. 520 . 
In order to keep the flour and fat from packing, bits of the cotton were distributed throughout the cone. The cone was stoppered with the remainder of the cotton. The cones and their contents were weighed on the sensitive balances. Then they were dried in a vacuum disiccator over sulphuric acid until they showed a constant weight.

The dried samples were put into the soxlet fat extraction apparatus. Ether which had been dried for twenty-four hours over sodium was used for the extraction. The extraction was continued for twenty hours. Then the cones were removed and allowed to evaporate free from ether. They were put again into the vacuum desiccator to extract moisture that they had absorbed from the air and they were finally weighed on the sensitive balance to get the loss in weight after the fat was extracted

TABLE IX

Quantitative Extraction of Fat From Pastry.

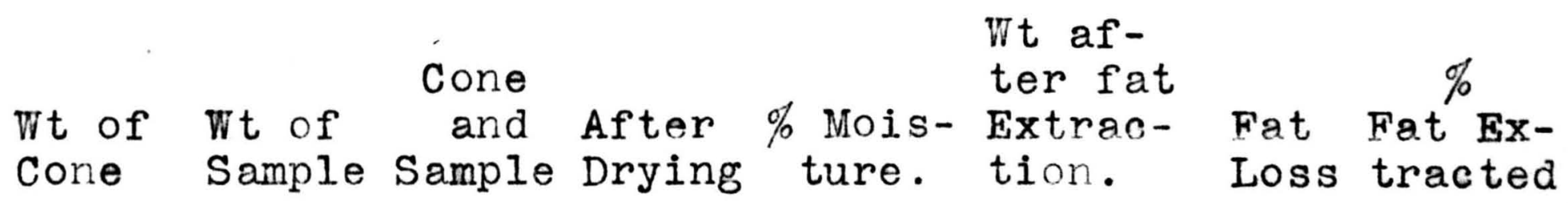

Cooked

$$
\begin{array}{rrrrrrrrr}
\text { I } & 1.6908 & 6.4050 & 8.0958 & 7.9237 & 2.68 \% & 5.8090 & 2.1147 & 33.8 \\
\text { II } & 2.1273 & 4.0535 & 6.1808 & 6.0632 & 2.9 \% & 4.7355 & 1.3277 & 33.7 \\
\text { III } & 1.6763 & 7.3560 & 9.0323 & 8.8387 & 2.67 \% & 6.4125 & 2.4262 & 33.9 \\
\text { Raw } & & & & & & & & \\
\text { I } & 1.5468 & 4.9595 & 6.5063 & 6.0592 & 9.03 \% & 4.2830 & 1.7762 & 39.3 \\
\text { II } & 1.2888 & 3.5855 & 4.8743 & 4.5743 & 8.3 \% & 3.2160 & 1.3583 & 41.0
\end{array}
$$


Average $\%$ of fat extracted from raw flour and fat, 40.2 Average $\%$ of fat extracted from pastry made from same mixture, 33.8 Conclusion

The results from this experiment indicate that not all of the fat in the cooked pastry was extracted. These results were delayed until after the constants of the fat were determined so the note may be made here that the iodine absorption number and saponification number of the cooked fat was open to error. It is suggested by Weibull that the fat should be extracted by means of $\mathrm{H}_{2} \mathrm{SO}_{4}$.

Summary

1. The fat in cooked pastry is not as thoroughly extracted as that from the raw fat and flour. This may be a source of error in the conclusions which are drawn below comparing the raw and cooked fat in pastry.

2. The iodine number of oleo alone and oleo extracted from the fat and flour mixture was changed from 71.3 to 72.25. Cooking the fat lowered the iodine number to 68.4 .

3. The saponification number of the fat was lowered by cooking in pastry. 
The Use of Various Fats in Pastry Purpose of Experiment

To Compare:

1. The appearance of dough when made of different fats: Butter, oleomargarine, crisco, lard, corn oil, wesson oil, compound, beef fat, and beef fat and oil mixed.

2. Different proportions and methods of mixing pastry fats as to: Lightness, moisture, texture, and flevor.

Methods of Work

Preparing the pastry - The quantities of materials used were weighed to tenths of a gram upon the Fairbanks white pan balances. All the flour was weighed in the same enamel pan and then transferred to the various mixing bowls. Flour to be used with the unsalted fats was salted with one-fourth teaspoon of salt. The fats and oils were weighed into dry beakers and transferred from the beaker into the flour. The fats were added to the measured quantities of flour and mixed with a spatula until the mixture was of a meal like evenness. Then the liquid was added to the dough until it would hold together. An attempt was made to keep the extent of mixing approximately the same for the different fats. The dough was rolled out upon a floured board. 
In order to have the pastry of uniform shapes, strips of wood were put on each side of the board so the depth to which the rolling pin would roll was regular. The dough was cut with a biscuit cutter. Only the first rolling was used in the experiment. The two biscuits used from each mixture were weighed before and after baking.

To have the baking conditions uniform, all the pastries were cooked at once, the temperature recorded and the length of time they were kept in the oven. The cooked crusts were not welghed until they were sufficiently cool to avoid a large error in weighing.

Determination of Specific Volume - To determine the specific volume of the cooked crusts, a method was used which is suggested by H. L. Jackson ${ }^{46}$ and was used in this labaratory in 1915 by Miss Wallace ${ }^{47}$ in her determination of the specific volume of cooked foods. In the present experiment, how ever, rape seed was used in place of hemp or millet seed.

The volume of the seeds, $510 \mathrm{cc}$, divided by their weight in grams, 340 , gives a specific volume for one gram of the seeds of 1.4 .

46

Jackson, H. I. Jour. Ind. and Eng. Chem. Dec. 1914, p. 998 .

47

Wallace. "The Most Favorable Temperature for Cooking Some Typical Foods", M. U. Thesis, 1915, 92. 75-84. 
To find the specific volume of the pastry, the weighed samples of each kind of crust were placed in the can in which there was already a portion of seed to hold the crusts in an upright position so the seeds put in later wou? d fall around them more easily. Then the can was carefully filled to or erflowing with the seed and the excess leveled off with a spatula. The volume of the excess seed represented the volume taken up by the samples of pastry. The volume of the excess seed was determined by weighing the seed and multiplying its weight in grams by 1.4

To calculate the specific volume of the pastry, the volume of the seed displaced was divided by the weight of the pastry.

The flavor of the pastries was determined by having persons who did not know which fats were used taste the samples and attempt to identify the fats used. 


\section{Use of Oils}

In working with the oils in pastry, the proportions and method of mixing first attempted were the same as those used with the solid fats. Since the large quantity of fat made a paste with the flour, less fat was used and even then much less water was required. In the hope of getting more water mixed into the pastry the water was added to the fat and the two mixed until they formed a temporary emulsion. The emulsion was added to the flour and mixed to a dough. In this way more water was added without making the dough too soft to roll easily. Since the pastry made with oll was less light, baking powder was added to the flour in some case TABLE X

Variation in quantity of Fat and 011

$\begin{array}{ccccc} & \text { Wt of Wt of Wt of Wt of } & \text { Vol. } \\ \text { Name } & \text { Wt of fat Flour Water Dough Crust Loss in } \\ \text { grams grams grams raw Cooked } \% & \text { cc Sp. }\end{array}$

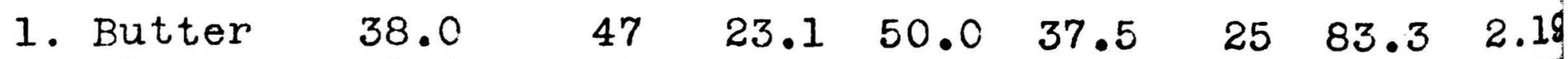

$\begin{array}{lllllllll}2.01 e 0 & 38.0 & 47 & 23.1 & 50.2 & 38.5 & 23 & 87.5 & 2.27\end{array}$

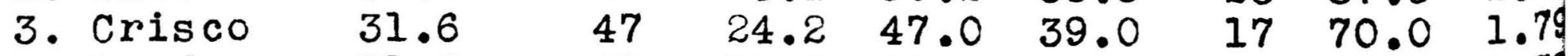

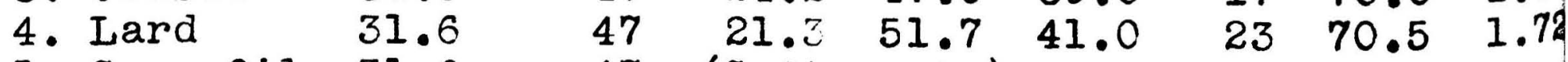

5. Corn 0il $31.6 \quad 47$ (Soft paste)

6. Wesson Oil $31.6 \quad 47$ (Soft paste)

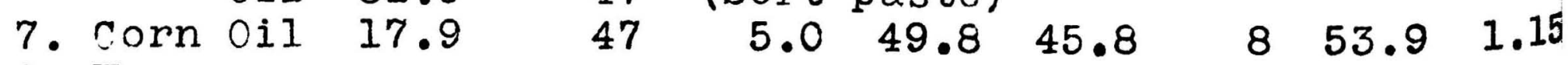

8. Wesson $\begin{array}{lllllllll}\text { Oil } & 17.9 & 47 & 6.8 & 52.2 & 45.0 & 14 & 54.6 & 1.21\end{array}$

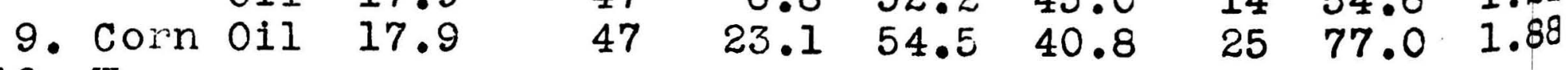
10. Wesson Oil 23.1 $\begin{array}{lllllll}47 & 17.3 & 53.5 & 41.5 & 22 & 68.0 & 1.63\end{array}$ 
TABLE XI

Keeping the Fat Content Uniform

Fat Flour Water $\stackrel{\%}{\%}$ of $50 \mathrm{gr}$. of grams grams Added grams grams \% cc

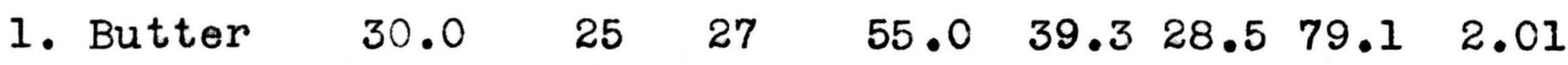

$\begin{array}{llllllllll}2 . & 01 e 0 & 30.0 & 25 & 27 & 54.5 & 38.5 & 29.0 & 83.0 & 2.15\end{array}$

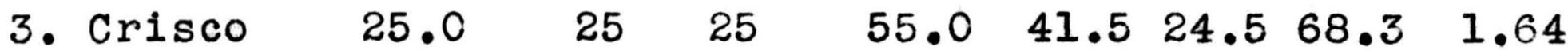

4. Compound 25.0 $25 \quad 25 \quad 51.5 \quad 38.3 \quad 25.0 \quad 62.2 \quad 1.62$

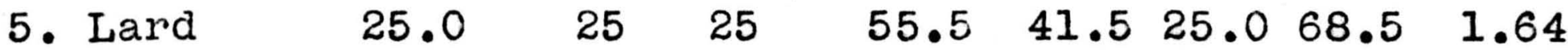

6. Wesson 01125.0 $20 \quad 21 \quad 59.5 \quad 45.024 .3 \quad 49.7 \quad 1.10$

7. Corn 0il 25.0 $20 \quad 21 \quad 57.0 \quad 43.024 .5 \quad 51.8 \quad 1.20$

8. Beef Suet $25.0 \quad 25 \quad 25 \quad 44.5 \quad 34.0 \quad 23.6 \quad 65.1 \quad 1.91$

9. Beef Suet 17.0 )

$\begin{array}{llllllllll}\text { and } 0 i 1 & 8.0 & 25 & 25 & 45.6 & 34.5 & 21.0 & 64.4 & 1.86\end{array}$

\section{TABLE XII}

The Uee of Baking Powder With Oil Pastry.

Fat Flour Water Dough Crust Loss Vol. Sp. Vol. $50 \mathrm{gr}$. of grams grams grams grams \% cc

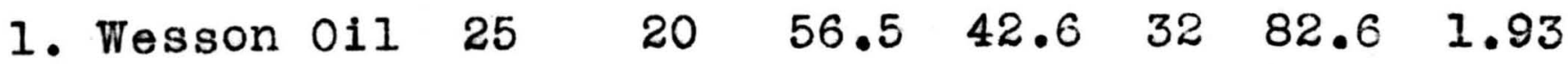

2. Wesson 0il $15 \quad 35 \quad 59.0 \quad 45.2 \quad 30 \quad 100.0 \quad 2.21$

3. Wesson 0il $15 \quad 30 \quad 56.0 \quad 42.6 \quad 31 \quad 98.0 \quad 2.30$ 


\section{TABLE XIII}

Summary of Experiments Done With Oil Pastry Methed
of Mix Wt of Wt of Loss Sp.
Wt of Fat Flour Water ing Dough Crust \% Vol.

1. Corn

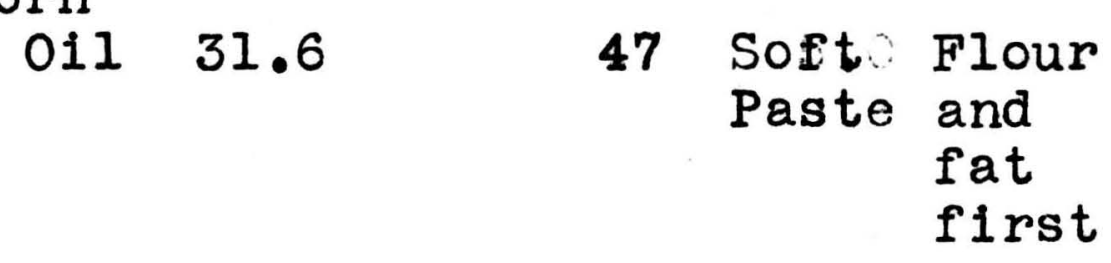

2. Wesson

01131.6

$47 \quad " \quad$

3. Corn
01117.9
$47 \quad 5.0 \quad 1$
$49.8 \quad 45.8 \quad 8.01 .50$

4. Wesson

0 il 17.9

$47 \quad 6.8 \quad "$

$62.2 \quad 45.0 \quad 14.0 \quad 1.21$

5. Corn

$$
01117.9
$$

$47 \quad 23.1$ Fat

\section{and}

Water

First $\quad 54.5 \quad 40.8 \quad 25.0 \quad 1.88$

6. Wesson

01123.1

$\begin{array}{lll}47 & 17.3 \quad 1\end{array}$

$53.5 \quad 41.5 \quad 22.0 \quad 1.63$

7. Corn

$$
\begin{array}{lllllllll}
011 & 25.0 & 50 & 20.0 & \prime & 57.0 & 43.0 & 24.5 & 1.20
\end{array}
$$

8. Wesson

$$
\begin{array}{lllllllllll}
0 \text { il } 25.0 & 50 & 20.0 & n & 59.5 & 45.0 & 24.3 & 1.10
\end{array}
$$

9. Wesson

$$
\text { OII } 25.0 \quad 50 \quad 20.0
$$

10. Wesson

$$
01115.0
$$

11. Wesson

$$
\text { Oil } 15.0
$$

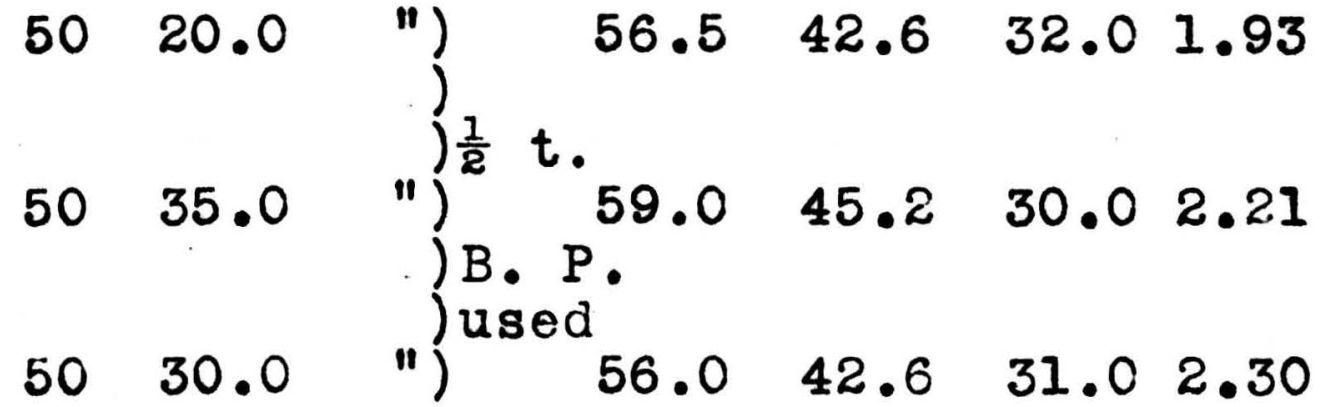


Discussion of Results

1. The Mixing of Dough - In the experiments reported 4 in table $\mathrm{X}$ the attempt was made to keep the proportions of flour, fat, and water constant--1 cup flour, $1 / 3$ cup fat, and $1 / 4$ cup liquidr- The fat in the butter and oleomargarine was figured as $83 \%$ of the weight, making 38 grams of butter or oleomargarine contain 31.6 grams weight of fat. When the oils were added to the flour as had been done with the solid fats, the oils made a soft paste with the flour so that it could not be used for making pastry. Therefore, the proportion of o1l was lowered--table X, Nos. 7 and 8-- so that the oll and flour made a mixture of meal like congiatency. This was done with about one-half as much oil as was used of solid fat. The amount of moisture which could be added to this mixture was very small--experiments 3 and 4 in table XIII. The next experiment with oil--table XIII, No:: 5-contained the same amount of fat but more water was used. This was made possible by mixing the fat and water before they were added to the flour. It seems that when the oil gets mixed with flour it prevants water from mixing with the flour so that it will form gluten. If the water is mixed wi th the flour first a tough mass results which makes the addition of fat difficult. Hence the attempt was made to mix the fat and liquid first so that the liquid should get some chance to develop gluten. The result was a dough which contained more moisture without bein too 
soft to handle. The reason for adding more moisture was to give the pastry a greater amount of steam for a rising agent, and a greater proportion of moist heat to cook the starch in the flour, as well as to develop more gluten to hold in the rising agents, steam and air.

The doughs made with oils seemed to have less bulk even though the same weight of materials was used. The biscuits made from these doughs, al though made to have approximately the same volume as those from the doughs made with solid fats, averaged a weight of 55 grams while the latter averaged 52 grams. Therefore, the oils seem to make a somewhat heavier dough. The oil doughs had an o1ly appearance if as much as 25 grams of oil were used. If a small proportion of oil was used it made oily streaks throughout the dough. Hence, the appearance of the raw dough was somewhat unattractive.

In using the solid fats they were all taken at the temperature of the room which was about $65^{\circ} \mathrm{F}$. At this temperature the compound used (table XI) was somewhat soft so that the dough made from it with $25 \mathrm{cc}$ of water was softer than the others. The amount of water in the butter and oleo, 4.7 grams made that much excess of water in these doughs. It was intended that 4.7 grams of water should be added to the 25 grams used with the 100\% fats, but when mixing these doughs a consistency of dough similar to those made with butter and oleo was secured when 25 cc of water were used, 
so the extra water was not added. It seems that the water in the butter and oleo is mixed so thoroughly with the fat that it has no effect in softening the dough in mixing. This probably accounts for the greater specific volume of the pastry made with those fats.

The appearance of the doughs made with the solid fats was very much the same in all cases except that the butter made a dough with a yellowish color, and that the dough made with compound was softer due to the softness of the fat at the temperature used. The mixing was in each case easy and the dough was not difficult to roll. It was fairly smooth and slightly spongy in appearance. There were no oily streaks in $1 \mathrm{t}$.

The doughs required from twelve to fifteen minutes to cook when put into an oven registering $250^{\circ} \mathrm{C}$.

2. The Cooked Crusts - (a) The pastries containing the butter and oleo were inclined to brown more easily than those made of fats which contained no casein.

(b) When no baking powder was used, the lightest pastries was, in each case, those containing the highest proportions of water. Butter and oleomargarine made lighter pastries than the other solid fats when the only difference $i$ in proportions was the extra 4.7 grams of moisture in the butter and oleo, and the baking was done at the same temperature. 
(c) The addition of more water to the oll pastries made a change in the specific volume of from 1.15 and 1.21 to 1.88 (table I, Nos. 7,8 , and 9.).

(d) Baking powder added to the oil pastries caused them to become lighter.

(e) The method of adding the oil and water made much difference in the texture and lightness of the resulting crust.

Comparing oil pastry $\mathrm{X}$, No. 7 (oil $17.9 \mathrm{gr}$. water $5 \mathrm{gr.}$ ) in which oil was mixed with flour, with pastry 9 (oil $17.9 \mathrm{gr}$. water $23 \mathrm{gr.}$ ) in which the oil and 23 grams of water were mixed before adding to the flour, we find pastry $\mathrm{X}$, No. 7 becoming heavy, crumbly, and too tender, while pastry X, No. 9 is smooth, light, but almost tough. When more oil is used as in X, No. 10 oil 23.1 gr. water 17.3 gr., (mixed before adding to flour) we find the crust smooth, tender, but not crumbly, although five grams more of oil were used than in $X$, No. 7 .

In the experiment in which all the fats are kept constant (table XI), and the water varied as little as possible, yet there is a correlation between the quantity of water and the lightness of the pastry. 
The Use of Various Fats in Cakemaking.

Purpose of Experiment

1. To compare the texture and flavor of cakes made from vorious fats.

2. To compare the cost of cakes made from the different fats.

Method of Work

The proportions used for the cakes were from the following recipe: Flour, 3 cups; sugar, $1 \frac{1}{2}$ cups; butter, $2 / 3$ cup; eggs, 2 ; water, $7 / 8$ cup; baking powder, 6 teaspoons.

The cakes were made on the scale of one cup of flour.

The flour used was a standard pastry flour. The weight of a cup of flour was taken as 95 grams and the weight of a cup of sugar as 200 grams.

In order to keep the proportions and mixing as nearly uniform as possible in the different cakes as much mixing as possible was done at one time. The recipe for one small cake was multiplied by twelve. This gave

$$
\begin{aligned}
& \text { Flour } 1140 \text { grams } \\
& \text { Sugar } 1170 \text { grams } \\
& \text { Baking powder } 50 \text { grams } \\
& \text { Total of } 2360 \text { grams of dry ingredients }
\end{aligned}
$$


and water $3 \frac{1}{2}$ cups, eggs 10 whites and 6 yolks were used in the liquid ingredients.

All te dry ingredients were sifted together four tim $\mathrm{s}$ to get them uniformly mixed. Then, since the totel weight came fairly near to 2400 grams, the weight of dry ingredients for each cake was taken as 200 grams. Into each of the eleven mixing bowls was weighed 200 grams of the dry mixture. To the portions which were to be used with the unsalted fats was added one-third teaspcon of salt.

The eggs were broken into a large bowl and beaten until they were well mixed. The water wes added to the eggs and the whole beaten until it looked uniform in color. Into each of eleven smaller bow is was weighed 100 grams of the water and egg mixture. To keep the egg mixture constant, it was stirred before each 100 grams was removed.

The fats used in the cakes were corn 011, wesaon oil, butter, crisco, lard, mutton fat, beef fat, a mixture of mutton fat 2 parts and corn 0111 part, and one of beef fat 2 parts and corn oil 1 part. They were measured into small beakers. 40.8 grams of each of the fats and oils was taken except in the case of butter, of which 49 grams was taken so the fat content of the butter cake would be the same as that of the other cakes. The solid fats were melted by putting the beakers into hot water. 
Tin pans about seven inches square were us ed for the baking. They were oiled with wesson oil, and floured to keep the cakes from sticking. The pans were prepared and the gas over heated to a temperature of $185^{\circ} \mathrm{C}$.

Each cake was mixed by pouring the melted fat or oil into the water and egg and stirring it until slightly mixed, and then putting the liquid mixture into the dry mixture of flour, sugar, and baking powder, and beating vigorously until it looked smooth. This took about 200 strokes. In mixing the cakes made of the harder fats alone, namely, mutton and beef fat, the melted fat, when put into the liquid, at once solidified into little chunks which could not be evenly mixed into the batter.

The batters were baked at $185^{\circ} \mathrm{C}$ for 30 minutes. The cakes, when baked, were allowed to cool before they were examined. Then they were arranged so that the experimenter could identify them and a number of persons were asked to taste them and make an effort to identify the fats used. The results are reported in tabular form. When the flavor was recognized a $f$ mark is used. When the flavor was not recognizable a - mark is used. 


\begin{tabular}{|c|c|c|c|c|c|c|c|c|c|c|c|}
\hline $\begin{array}{c}\text { Name of Oil or Fat } \\
\text { Used in Cake }\end{array}$ & I & I & II & $\begin{array}{l}\text { Numl } \\
\text { I I I }\end{array}$ & IV & $f_{\mathrm{v}}$ & vi & $\begin{array}{c}\operatorname{ctST} \\
\text { VII }\end{array}$ & $\begin{array}{l}\text { sting } \\
\text { VIII }\end{array}$ & IX & $\mathrm{X}$ \\
\hline Corn Oil & - & - & $t$ & - & - & - & - & - & $t$ & - & - \\
\hline Wesson 011 & - & - & - & - & - & - & - & - & - & - & - \\
\hline Butter & $t$ & $t$ & $t$ & $t$ & $t$ & - & $t$ & $t$ & $t$ & - & $t$ \\
\hline Crisco & - & - & - & $t$ & $t$ & - & - & - & - & - & - \\
\hline Beef Fat & $t$ & - & - & - & - & $t$ & - & $t$ & - & - & - \\
\hline 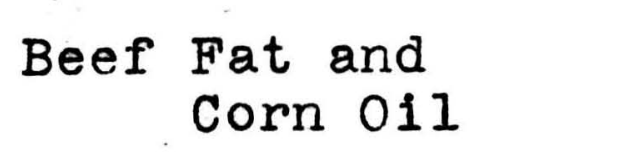 & - & - & - & - & - & - & - & - & - & - & - \\
\hline Lard & - & - & - & - & - & - & - & - & - & $f$ & - \\
\hline Mutton Fat & $f$ & $t$ & $t$ & $t$ & $t$ & t & $t$ & $t$ & $t$ & t & t \\
\hline $\begin{array}{l}\text { Mutton Fat and } \\
\text { Corn O1I }\end{array}$ & & & $t$ & $t$ & $t$ & $t$ & t & $t$ & $t$ & t & \\
\hline
\end{tabular}

The butter cake had a flavor peculiar to butter which most of the people tasting could recognize. However, after the cakes were a day old it took much care in tasting to recognize even the butter flavor. The corn oil was recognized by two people out of ten. The wesson oil could not be recognized. The crisco was slightly old and this was recognized by two out of ten people. The beef flavor was described by some as coming just after the bite of cake had been swallowed. The mojority of the tasters could not identify it at all. One person, an experienced cook, named the cake made of lard as soon as she tasted it. Not another of the ten people could recognize it. The mutton fat waa easily recognized by all of the subjects because of the peculiarly strong flavor of the sample. 
The cakes looked very much alike. They all seemed equally light. In both cases the cakes which contained beef fat had a browner crust than any other cakes. The cakes made of the beef fat and mutton fat alone were not so soft as the other cakes and were less tender. This toughness may have been caused by the fact previously noted that these fats did not mix evenly throughout the batter. A close examination of the texture show ed that the fat was not evenly mixed.

It was not found that the other fats tested made 8 difference in the texture of the cakes. They were all quite tender. Therefore, the shortening power of the oils, lard, crisco, and the compounds made with the beef fat and oil, and the mutton fat and oil, were practically the same as was that of the butter fat also when allowance was made for the $17 \%$ of substance other than shortening in the butter.

Comparison of the costs of the fats used in the cakes. Figuring the cost of the fat used in one ordinary sized cake ( 3 cups of flour), and basing the prices upon the table of costs recorded earlier in this paper, we find the fats to compare as follows: Butter $\$ .15$, crisco $\$ .06$, lard $\$ .972$, wesson oil $\$ .056$, corn oil $\$ .06$, beef fat $\$ .033$ and beef fat and oil \$.039. 
The Handling of Fats in the Home.

Purpose of Experiment

To try out:

1. Recommendations which have been made for removing the rancid flavor from fat.

2. Methods of removing the characteristic flavor and hardness of mutton fat.

Removing Rancidity

Method of Work

Rancidity of Fats - Materials used for removing the rancidity were water, sour milk, charcoal, limewater, and waterglass.

The fat which was used had been exposed to the light and atmosphere for two months. It was the fat separated from the casein and water of a brand of oleomargarine. The fat had a very piercing odor of rancidity.

It was measured out by one-half cupfuls into seven stewpans. Into pan one was put one cup of water; pan two, one-half cup of sour milk; pan three, six ohe-ineh long sticks of charcoal; pan four, one tablespoonful of $\mathrm{CaO}$ and one-half cup of water; pan five, one-half cupful of a solution of waterglass. One-fourth cup of water was added to pans 3 and 4 to keep the fat from burning.

All the pans were put upon the stove where they would keep hot but not boil. They were left for two hours. 
In the process of separating the fat from the other substances, the mixture was strained into beakers through flannel when necessary to remove solid substances. Onehalf cup of hot water was added to each beaker and they were set aside to allow the oleomargarine fat to separate and harden. One beaker was prepared which contained the fat that had not been treated in any way.

Testing the Rancidity - Although the rancidity of a fat does not run parallel wi th the acidity, one of the changes which is evident in a rancid fat is an increased acidity. Hence the acidity of the fats which were treated was determined to get an idea of the chemical change which had been made.

To observe the change in flavor, the fats were salted like butter and tasted upon hot bread.

TABLE XIV

Acidity of Rancid Fat

Fat Treated Wt. of cc of Times Fac-Divided by Times Ave. With

Sample $\mathrm{NaOH}$ tor 1.123 Wt of Fat. 5.6108

\begin{tabular}{lllllll}
1 Nothing & a 10.126 & 8.65 & 9.71 & .950 & 5.33 & \\
2 Water & b 10.510 & 8.90 & 9.99 & .950 & 5.33 & 5.33 \\
\multirow{3}{*}{ Charcoal } & a 10.002 & 2.50 & 2.31 & .280 & 1.57 & \\
& b 10.407 & 2.70 & 3.03 & .290 & 1.62 & 1.59 \\
4 Milk & a 10.386 & 2.70 & 3.03 & .290 & 1.62 & \\
& b 10.255 & 2.55 & 2.86 & .280 & 1.57 & 1.59 \\
5 Limewater & a 10.225 & 2.60 & 2.91 & .280 & 1.57 & \\
\multirow{2}{*}{ Waterglass } & b 10.105 & 2.80 & 3.25 & .320 & 1.79 & 1.68 \\
& a 10.706 & .35 & .39 & .036 & .20 & \\
& b 10.551 & .30 & .34 & .032 & .18 & .19
\end{tabular}


Discussion of Results

The method of tasting was very inadwquate because the odor of rancidity in the original fat had dulled the sense of recognition of the other flavors. The original fat smelled so strong that it was not tasted. The fat which had been treated with water had more of a rancid odor than was noticed after the use of the charcoal, milk, or limewater. The milk gave an added flavor to the fat. No decided difference in the rancid taste could be distinguished in $2,3,4$, and 5 . The waterglass used was alkaline and gave the fat an alkaline taste making it unfit for use.

Conclusion

The use of water, milk, charcoal, or limewater undoubtedly improves the flavor of the fat considerably. of these materials the ones most convenient to use were water or milk as there was not an objectional foreign substance to remove afterwards.

\section{Modifying the Flavor of Mutton Fat}

Method of Work

Since the mutton fat in the cake experiment was so decided in flavor an attempt was made to correct this disagreeable feature.

Fresh mixed mutton fat was secured and rendered in the following ways:

1. In double boiler without adation of other substance. 
2. With charcoal and water.

3. With sour milk.

The rendered fat was strained through flannel and each sample of fat was mixed with one half of its weight of corn 011 .

Cakes were made using the same proportions of ingredients as were used in the cake experiment previously deseribed. The mixing and baking was as near the same as could be secured. One butter cake w as made to compare with the mutton fat cakes. After the cakes cooled, they were sampled. Since the results were not entirely satisfactory, anoher experiment was made in order to get a fat of low er melting point and to further test the flavor of the fats. To the mutton fats 1,2 , and 3 was added equal parts of cottonseed oil and the samples thoroughly mixed. When cool they had formed fats about as soft as lard. These fats were mixed into biscuits and baked. While still hot they were sampled to get the difference in flavor.

Results

1. In the cake experiment the mutton fat cakes were harder than the butter cake. The flavor was not decided as it was in the first cake experiment. Probably the first fat was old or from a different aged animal. People who were unsuspecting did not recognize anything disagreeable 
about the flavor of any of the cakes. There was a tendency howerer for the hard fat to form upon the inside of the mouth. For this reason the fats were made softer and used in biscuits.

2. The biscuits were quite tender and pleasing in flavor. A preference was expressed for those made with the fat rendered with milk. The fat number 2 was not recognizable. The fat number 1 was recognized by one out of five people who tasted the biscuits.

\section{Conclusion:-}

1. The flavor of mutton fat as purchased varies.

2. It may be modified by the use of charcoal and water, or by the use of sour milk.

3. The fat used was satisfactorily softened by ading an equal quantity of oil.

4. With mutton tallow costing $10 \not f$ a pound and the oil costing $20 \&$ the cost of a pound of this fat would be 15 cents. 


\section{FINAL SUMIARY}

I The Use of Fats in Frying.

1. The fats best suited for deep frying are those which do not smoke at a temperature below 190 degrees.

2. The fat has a low smoking temperature when it has a high acid content due to (a) the natural acidity of the fat, (b) added acidity, (c) superheating. 3. The absorption of fat in frying is incluenced bya. - The temperature at which the food is fried.

b. - The composition and shape of the food. c.-The kind of fat used in frying-solid fats are not absorbed to as great an extent as is oil.

II The Use of Fats in Pastry.

1. The fat cooked in pastry had a lower iodine number and saponification number than the original fat. 2. Fat is incompletely extracted from cooked pastry. 3. The solid fats were equally efficient in shortening the pastry.

The method of mixing the oil pastry had much to do with the proportion which could be used, and the tenderness and lightness of the pastry. The baking powder helped to make the oil pastry light.

The proportion of water used in the pastries 
influenced the lightness.

III The Use of Fats in Cakemaking.

1. If fresh fats are used there is not a noticeable difference in the flavor or texture of the cakes, unless the fats are very hard.

2. Considerable difference in cost may be made by subatituting other fats for butter in cakemaking.

IV Handling of Fats in the Home.

1. The strong flavor of a rancid fat may be removed or modified by heating it with water, milk, charcoal or limewater.

2. The flavor of mutton fat may be modified by rendering it with milk or charcoal.

Its hardness may be corrected by adding an oil to it.

\section{BIBLIOGRAPHY}

1. Blunt, Katherine, and Feeney, Clara. "The Smoking Temperature of Edible Fats." Journal of Home Economics Vol VII (1915) pages 535 to 541.

2. Burtt-Daby, Joseph. Maize; Its History, Cultivation, Handling and Uses. New York, Longmans. 1914. pages 696, 785. 
3. Bateman, J. T. "Deodorizing Oils." Brit. 24605. Jan 6, 1914. Note in Chemical Abstracts, June 20, 1916 page 1715.

4. Bernegan, L. Edible Palms 0il. Ger. 288209. Mar 4, 1914. Note in Chemical Abstracts, Sept 20, 1916 page 2311.

5. Cotton Seed and Its Products. Farmers Bulletin number 36. U. S. Dept. of Agriculture, Washington, D. C. 1896 .

6. Daniels, Amy, and Strickler, Leola. "A Comparison of the Digestibility of Starch in Typical Batter and Dough Mixtures." Journal of Home Economics Vol IX No. 3, 1917, pages 109-114.

7. Emery, J. A. "The Use of Metallic Containers for Edible Fats and 0ils." Report of the Bureal of Animal Industry. U. S. Dept. of Agriculture, Washington, D. C. 1909 , pages 265-282.

8. Farmer, Fannie Merritt. "The Boston Cooking-School Cook Book." Boston, Iittle Brown \& Co. 1914.

9. Fejer, A Von. "The Influence of the Melting Point of Non-emulsified Fats on the Rate of Leaving the Stomach." Bischem. Ztochr. 53 (1913) No 1-2, pages 168-178. $\mathrm{Ab} B$ in Experiment Station Record 30, page 464.

10. Fulmer, E., and Mancheater. T. C. "Changes in the Character of Fats During the Process of Cooking." Journal of the American Chemical Society. Vol XXX 1907, page 1477.

11. Gerlach, "Assimilation of Animal and Vegetable Fat by Man." Abs in Experiment Station Record 20, page 776. 
12. Hill, Janet McKenzie. "The Whys of Cooking." Cincinnati. Proctor and Gamble, 1916 page 6.

13. Holde, D--Mueller, Edward. "Examination of the Hydrocarbon Oils." London. Wiley and Sons. 1915, pages 287-360.

14. Holland, E. B., Reed, J. C., and Buckley, J. P. "Improved Methods of Fat Analysis." Massachusetts Agricultural Experinent Station Bulletin, No. 166. Dec. 1915. Amherst, Mas8.

15. Holmes, A. D., and Lang, H. I. "Fats and Their Economical Use in the Home." U. S. Dept. of Agriculture Bulletin No. 469. Washington, D. C. December, 1926.

16. Jackson, H. I. "Egg Albumin in Baking Powder." Journal of Industrial and EngineeringChemistry. Decernber, 1914, page 998.

17. Kienzl, N. "On the Absorption of Several Kinds of Fat in the Intestinal Tract of Man." Oesterr, Chem. Ztg. I 1898 , No. 6 pages 198-202.

18. Klimont, J. and Mayer, K. "Use of Hydrogenated Fish Oil in the Manufacture of 01 eomargarine." Ztschr. Angen. Chem. 27, 1914. Abstract in Journal of the Society of Chemical Industry. Vol. 34, 1915, No. 3, page 148.

19. Langworthy, C. F. and Holmes, A. D. "Digestibility of Some Animal Fats." U. S. Dept. of Agriculture Bulletin No. 310, 1915, pages 23. 
20. Langworthy, C. F., and Holmes, A. D. "Studies on the Digestibility of Some Animal Fats." U. S. Department of Agriculture Bullet in 507, March 24, 1917.

21. Langworthy, C. F., and Hunt, Caroline, L. "Natt on and Its Value in the Diet." Farmers Bulletin 526. U. S. Department of Agriculture, 1913.

22. Lehmann, K. B. "Are the Hardened Fat suitable for Human Food?" Chen. Ztg. 38(1914) No. 75, pages 798-790. $\mathrm{Ab}$ s in Experiment Station Record 32, page 660.

23. Lewkowitsch, Jilius Isidor. "The Chemical Technology and Analysis of 0 ils, Fats, and Waxes." 3 Volumes, Edition 5. London. MacMillan \& Co. 1913.

24. Lowenstein, A., and Vollertsen, J. "The Effect of Free Fatty Acids upon the Flash and Fire Points of Animal Fats and Oils." Journal of Industrial and Engineering Chemistry. Vol. 7, 1915, No. 10, page 850 .

25. Masters, Helen, and Snith, Henry, L. "Changes in the Character of Fats During the Process of Cooking." The Analyot Vol. 39,1914 , No. 461, pages 347-350.

26. Mills, Ketherine H. "Moking Cake." Cornell Reading Courses, N. Y. College of Agriculture, Vol. IV, No. 73, 1914, pages 9 and 10.

27. Montgomery, Ward and Company. "Groceries." Chicago, Dec. 1916, pages 24 and 25.

28. Moore, J. F. "The Relative Digestibility of Some Fdible Fats and Oils." Arkansas Station Bulletin No. 78, 1903, pages 33-41. 
29. Nagel, Iskar. "The Rancidity Fats and the Refining of Rancid Fats and Oils." American Chemical Journal, Vol. 23, 1900, No. 2, pages 173-176.

30. Rankwitz, E. "Rancidity and the Acidity of Fats." Z. Offent. Chem. Vol. 20, page 336, 1914. Abstract in Chemical Abstracts. Vol. 9, page 1350.

31. Sadtler, Samuel P. "Industry of the Fats and Fatty 0ils." Industrial Organic Chemistry, 4 th edition. Philadelphia, Lippincott Co. 1912.

32. Sears, Roebuck and Co. "Your Grocery Store." Chicago, April, 1917, page 4l.

33. Sherman, Henry C. "Edible Fats and Oils." Food Products. New York, Macmillan \& Co. 1916, pages 366-396. 34. Susmann, P. O. "Are the Hardened Fats Suitable Food for Man." Arch. Hyg. Vo. 34, 1915, No. 2-3, pages $121-145$.

35. Taylor, Ehma L. "Cold versus Warm Water in Pastry." Journal of Home Economics. VIII , 1916, page 189. 36. Thoms, H, and liuller, F. "The Use of Hardened Fats for Food Purposes." Arch. Hyg. Vol. 84. 1915, No. 1 , pages 54-77. Abstract in Chemical Abstracts 8:, page 1642 .

37. Thompson, H. C. and Bailey, H. S. "Peanut Oil." U. S. Dept. of Agriculture Farmers Bulletin, No. 751. August, 1916.

38. Wagner, H. Walker R. and Oestermann, H. "The Inluence of Light upon Fats under the Absolute Exclusion of Air." Zertsch. f. Untersuch der Nahrangs und Genussmittel. Vol 25, 1913, page 704. Abstract 
in Chemical Abstracts $7^{3}$, page 3675.

39. Wallace, May. "The Most Favorable Temperatures for the Cooking of Some Typical Foods." Thesis, University of Missouri, 1915, pages 75-84.

40. Ward, Artemu, "The Grocers Encyclopedia." New York, Kempoter Printing Co., 1911.

41. Weibull, M. Svensk-kemisk Tidskrift. No. 5, 1892. Abstract in Experiment Station Record. Vol. 5, page 520.

42. Watson, Mary Urie. "Mixing Fat into Dough." U. S. Dept. of Agriculture Farmers Bulletin No. 360, page 32.

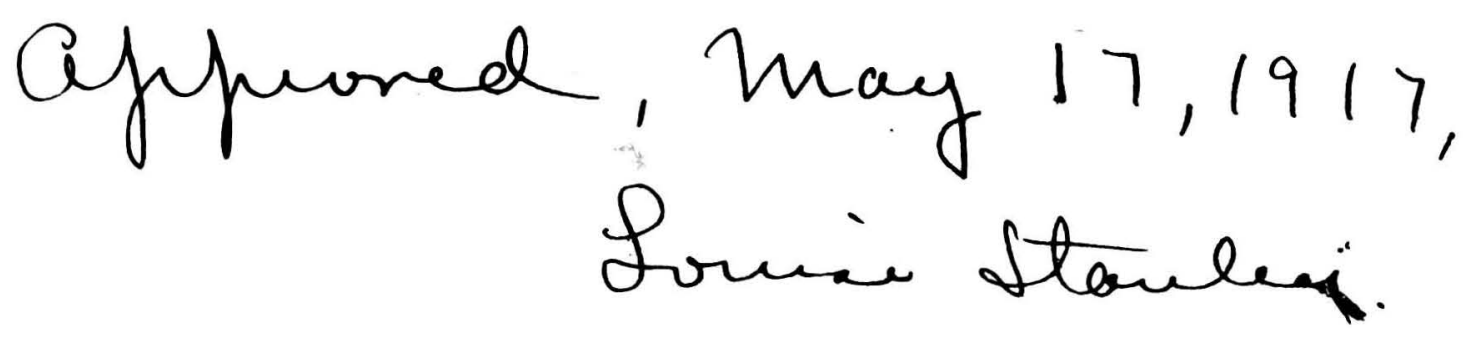

